\title{
ORIGEM E DESENVOLVIMENTO DAS GOLDEN SHARES ${ }^{1}$
}

\section{ORIGIN AND DEVELOPMENT OF THE GOLDEN SHARES}

Juliana Krueger Pela*

\begin{abstract}
Resumo:
$\mathrm{O}$ artigo trata da origem das golden shares, no Reino Unido, e de sua adoção na França, Itália e, principalmente, no Brasil. Além disso, descreve as decisões da Corte de Justiça da União Européia a respeito do tema. Ao final, sistematiza as principais características das golden shares e aponta os debates surgidos, no Direito Privado, em razão da emissão de golden shares por sociedades anônimas.
\end{abstract}

Palavras-chave: Golden share. Privatizações. Direito societário. Tipicidade das sociedades anônimas.

\begin{abstract}
:
The article refers to the origin of golden shares, in the United Kingdom, and to its adoption in France, Italy and, mainly, in Brazil. Additionally, it describes the decisions of the European Court of Justice concerning this issue. Lastly, reports the golden shares' main characters and also reviews the arguments raised, in within Private Law, in connection with the issue of golden share by companies.
\end{abstract}

Keywords: Golden share. Privatization. Corporate law. Legal type anonymous corporation.

\section{Introdução}

Há mais de cinqüenta anos Tullio Ascarelli afirmou, com a expressividade que lhe é própria, que a atividade dos comercialistas por vezes se assemelha à atividade dos engenheiros. Isso porque compete aos juristas não-somente distinguir entre lícito e ilícito, mas também criar "máquinas jurídicas", instrumentos que atendam às exigências e demandas econômicas e sociais, promovam a produtividade e a melhor alocação de riquezas. $^{2}$

\footnotetext{
1 O conteúdo do presente artigo corresponde aos dois primeiros capítulos da tese de doutorado da Autora, intitulada "As golden shares no Direito brasileiro". A tese, elaborada no período de março de 2001 a fevereiro de 2007, sob orientação da Prof. Associada Rachel Sztajn, foi defendida e aprovada por unanimidade, com voto de louvor, em 18 de junho de 2007. Em junho de 2008, a tese foi classificada em segundo lugar na seleção de teses do ano de 2007 promovida pela Comissão de Pós-Graduação da Faculdade de Direito da Universidade de São Paulo. Essa classificação motivou a publicação do presente artigo. Dessa forma, as referências legislativas, bibliográficas e jurisprudenciais estão atualizadas até fevereiro de 2007.

* Professora Doutora do Departamento de Direito Comercial da Faculdade de Direito da Universidade de São Paulo. Doutora em Direito Comercial pela Faculdade de Direito da Universidade de São Paulo. Bacharel em Direito, com especialização em Direito Empresarial, pela Faculdade de Direito da Universidade de São Paulo. Advogada em São Paulo.

2 Vale transcrever o seguinte excerto: "Questa fenomenologia ci torna a dimonstrare quella che vorrei dire l'opera di 'ingegnere' del giurista, quale si svolge innanzi tutto nella creazione di strumenti giuridici. Il nostro
} 
Um desses instrumentos é a chamada golden share. Exemplo nítido da atividade inventiva do direito empresarial, surgiu justamente para satisfazer as necessidades políticas e econômicas surgidas em momento de alteração das relações entre Estado e mercado.

A partir da década de 70, verificou-se uma crise de financiamento do Estado, que comprometeu a capacidade de investimento público e a própria eficiência na administração dos recursos confiados aos governos. Percebeu-se que era preciso conter os gastos públicos e realocar os ativos empresariais controlados pelo Estado. ${ }^{3}$ A política pública desenhada para atingir esses objetivos consistiu na transferência desses ativos às mãos dos particulares, que teriam maior capacidade de investimento e maiores incentivos para geri-los de forma eficiente. Tal política foi formalizada nos programas de privatização adotados por diversos países durante os anos $80 .{ }^{4}$

Enquanto política pública, a privatização procurou conciliar o valor da eficiência econômica, que era sua principal motivação, com outros objetivos relevantes, como a proteção de interesses estratégicos do Estado. ${ }^{5}$ De fato, os programas de privatização partiram da premissa de que a transferência aos particulares do controle das empresas então estatais adicionaria valor a esses ativos e aumentaria, por conseqüência, o bem-estar agregado. No entanto, essa transferência não poderia acarretar uma perda completa da ingerência do Estado sobre a administração desses recursos, pois isso poderia comprometer outros valores fundamentais para o Estado, como a segurança nacional. Os

problema di giuristi non è solo quello della distinzione tra lecito o illecito, ma anche quello della fantasia; quello della creazione di strumenti, vorrei dire di macchine giuridice, che possano conseguire determinate finalità, che abbiano freno e motore, che camminino, ma non vadano a finire nei fossi, che cioè contemperino esigenze diverse. I problemi sollevati da una economia industrializzata (o dal desiderio dell'industriali zzazione), rivelano sotto questo aspetto la loro novità rispetto alla problematica tradizionale. L'opera del diritto commerciale si è volta storicamente innanzi tutto nella creazione di nuovi strumenti giuridici, con la elaborazione delle società per azioni, dei titoli di credito, dell'assicurazione, istituti giuridici che sono stati gli strumenti dell'industrializzazione e che così hanno concorso a un effetivo aumento di ricchezza e senza $i$ quale le stesse invenzioni tecniche non si sarebbero potute realizzare quali fattori di benessere. La normativa giuridica deve essere dinamicamente considerata come una strutturazione per una maggiore produzione e una migliore distribuzione della ricchezza, fenomini non opposti, ma reciprocamente condizionati. E il compito di noi giuristi è di cooperare in questa opera, elaborando un arsenale di strumenti che possano servire a questo scopo". (ASCARELLI, Tullio. Varietà di titoli di credito e investimento. In: Problemi giuridici. Milano: Dott. A. Giuffrè Editore, 1959. t. II. p. 702).

3 A respeito, vide: DONAHUE, John D. The privatization decision - public ends, private means. New York: Basic Books, 1989. p. 14-37.

4 Sobre o tema, confira-se: MEGGINSON, William L.; NETTER, Jeffry M. From State to market: a survey of empirical studies on privatisation. Journal of Economic Literature, Stanford, v. 39, n. 2, June 2001. Disponível em: <http://ssrn.com/abstract=262311>. Acesso em: 17 abr. 2006.

5 Um panorama dos fundamentos das políticas públicas que têm por objeto a intervenção estatal nas companhias pode ser encontrado em CHEFFINS, Brian. Company law: theory, structure and operation. New York: Oxford University Press, 2000. p. 126-162. Segundo o autor, tais políticas costumam ter duas ordens de fundamento: a promoção da eficiência e outros objetivos dela diversos, como a própria justiça e a realização de ideais da comunidade. 
particulares, embora pudessem ter incentivos para a gestão mais eficiente dos recursos, já que participariam dos excedentes na forma de dividendos, não teriam incentivos equivalentes para zelar, por exemplo, pelos interesses nacionais.

Assim, fez-se necessário conceber um mecanismo que permitisse, a um só tempo, a transferência do controle societário dessas companhias a particulares e a reserva, nas mãos do Estado, de poderes que resguardassem os interesses nacionais, impedindo a participação de estrangeiros em setores estratégicos da economia. Tratava-se, justamente, da "ação de ouro". 6

Cuidava-se de título acionário representativo de uma unidade do capital social, que atribuía ao seu titular - o Estado - prerrogativas especiais, não proporcionais à sua participação no capital da sociedade, destinadas a resguardar interesses nacionais, como o direito de impedir o ingresso de acionistas estrangeiros no bloco de controle da companhia. ${ }^{7}$ Em sua origem, portanto, a golden share visava à satisfação de interesses públicos.

A partir do modelo britânico de privatizações e, justamente para satisfação de interesses nacionais, o mecanismo originalmente corporificado na golden share foi adotado, sob denominações diversas, em países como a França (action spécifique), Itália (poteri speciali), Alemanha (goldene Aktie e Spezialaktie), Bélgica (action spécifique), Portugal (acções preferenciais), Espanha (regime administrativo de controle especifico), Nova Zelândia (kiwi share), México e Brasil (ação de classe especial).

Posteriormente, porém, tais títulos acionários passaram a ser emitidos também por sociedades anônimas que se situavam fora do contexto das privatizações e da participação do Estado na economia, com o objetivo de atender a funções bastante distintas. Com efeito, a desproporção entre a participação acionária encerrada pelo título, de um lado, e os direitos por ele atribuídos ao seu titular, de outro, mostra-se particularmente útil para a estruturação do poder interno nessas companhias. Nesses casos, a golden share afasta-se de sua função original e desponta como importante instrumento de técnica societária.

No entanto, a adoção da golden share - tanto em seu modelo original quanto em sua aplicação no âmbito puramente privado - tem sido bastante questionada,

\footnotetext{
6 Conforme relatou Madsen Pirie, membro do Primeiro Gabinete do Governo Thatcher, a respeito do processo de privatização da companhia estatal britânica British Aerospace: "a privatização da British Aerospace levantou questões de segurança nacional. Foi perguntado se permitiríamos que tão importante indústria tivesse um controle estrangeiro. A resposta foi a introdução de uma 'ação de ouro'. Ela é detida pelo Governo inglês e pode ser ativada para garantir o controle acionário, no caso de a maioria das ações passarem para mãos estrangeiras". (PIRIE, Madsen et al. Privatização, mercado de capitais e democracia: a recente experiência internacional. Sem referência ao tradutor. Rio de Janeiro: Correio da Serra, 1988. p. 21).

SODI, Jacopo. Poteri speciali, golden share e false privatizzazioni. Rivista delle Società, Milano, n. 41, fasc. 2-3, p. 368-404, mar./giugno 1996. p. 377.
} 
principalmente nos países de direito continental e no plano do direito comunitário da União Européia.

Nos países de tradição jurídica romano-germânica, discute-se a licitude das golden shares face ao regime específico das sociedades anônimas e à taxatividade das espécies de ações. Essa discussão, já bastante adiantada na Itália e na França, também está presente no Brasil, como se pôde verificar, por exemplo, no conturbado processo de privatização da Companhia Vale do Rio Doce.

Por outro lado, no âmbito do Direito comunitário europeu, questionase a adequação das golden shares ao Tratado de Instituição da Comunidade Européia, notadamente às regras que proíbem restrições à livre circulação de capitais e investimentos entre os países-membros. A Corte de Justiça da União Européia inclusive já se pronunciou sobre o assunto, em relação às ações emitidas por companhias italianas, portuguesas, francesas, belgas, espanholas, britânicas e holandesas. ${ }^{8}$

Tais questionamentos conduzem a uma necessária análise da conformidade da golden share com o direito e, nesse sentido, serviram de ponto de partida para o trabalho.

2. As golden shares nos diversos ordenamentos jurídicos

\subsubsection{Reino Unido}

As golden shares têm origem no Reino Unido, no âmbito do processo de privatizações realizado, a partir de 1979, pelo governo da primeira-ministra Margareth Thatcher.

Embora a privatização das empresas públicas no Reino Unido não tenha integrado o programa eleitoral do partido conservador, ${ }^{9}$ tornou-se, nos sucessivos mandatos de Margareth Thatcher, a mais relevante política econômica do Governo. ${ }^{10}$ Diversas razões conduziram à adoção de um plano para privatização das companhias estatais, dentre

8 Referência feita aos casos C-58/99, C-367/98, C-483/99, C-503/99, C-463/00, C-98/01, C-282/04 e C-283/04, respectivamente.

9 Cf., entre outros, GRAHAM, Cosmo. Regulating public utilities: a constitutional approach. Portland: Hart Publishing, 2000. p. 14; GRAHAM, Cosmo; PROSSER, Tony. Privatizing public enterprises: constitutions, the State and regulation in comparative perspective. New York: Oxford University Press, 1991. p. 20 e ss.; MEGGINSON, William L.; NETTER, Jeffry M. op. cit., p. 3; e VICKERS, John; YARROW, George. Privatization: an economic analysis. Cambridge: MIT Press, 1989. p. 155.

${ }^{10}$ Para Madsen Pirie, a relevância da política de privatizações no Reino Unido é comprovada pela exportação do modelo a diversos outros países (PIRIE, Madsen. Blueprint for a revolution. 2. ed. London: Adam Smith Institute (Research) Limited, 1993. p. 6). 
as quais se costuma citar: ${ }^{11}$ (i) a influência das idéias neoliberais; (ii) a necessidade de diminuição dos gastos públicos, especialmente em função da crise econômica enfrentada pelo Reino Unido no final da década de 70 e início de 80; (iii) a necessidade de reduzir o volume de empréstimos concedidos pelo Estado às empresas públicas (Public Sector Borrowing Requirement - PSBR); ${ }^{12}$ (iv) a pretendida diminuição da intervenção estatal na administração das empresas e do poder dos sindicatos de trabalhadores estatais; (v) a promoção da eficiência e da competitividade das companhias; (vi) o incentivo à dispersão da propriedade acionária e à aquisição de ações por trabalhadores, com o conseqüente desenvolvimento do chamado "popular capitalism". ${ }^{13}$

Apesar de a diminuição da intervenção estatal na administração das empresas públicas constituir um dos evidentes objetivos da privatização, o Governo entendeu que, mesmo após a transferência do controle das companhias estatais a particulares, certo grau de intervenção ainda deveria ser mantido. Como grande parte das sociedades privatizadas tinha importância estratégica para a economia do Reino Unido e era incumbida da prestação de serviços públicos essenciais, não se podia permitir que tais companhias ficassem vulneráveis a determinadas circunstâncias, como falência, interrupção das atividades ou transferência de controle acionário, especialmente mediante a aquisição hostil (hostile takeover) por parte de estrangeiros. ${ }^{14}$

\footnotetext{
${ }^{11}$ Trata-se das razões indicadas por (VICKERS, John; YARROW, George. op. cit., p. 157). No entanto, conforme demonstram GRAHAM, Cosmo. Regulating public utilities: a constitutional approach. cit., p. 15 e SAUNDERS, Peter; HARRIS, Colin. Privatisation and popular capitalism. Buckingham: Open University Press, 1994. p. 18-19, as razões da privatização não se revelam perfeitamente compatíveis entre si, circunstância que demanda uma análise específica de cada caso.

12 John Vickers e George Yarrow esclarecem como a alienação do controle das empresas públicas poderia atingir esse efeito: "A more important difference arose from the Government's objective of reducing the PSBR, because the borrowings of a formerly nationalized firm are no longer part of the PSBR once the firm has entered the private sector. Moreover, as a result of a curious accounting definition, the proceeds from the sale of state assets directly reduce the PSBR because they are treated as "negative public expenditure."” (VICKERS, John; YARROW, George. op. cit., p. 158).

${ }^{13} \mathrm{O}$ popular capitalism caracteriza-se pela dispersão acionária decorrente da realização de pequenos investimentos individuais no mercado de capitais por parte de larga parcela da população (GROUT, Paul. Popular capitalism. In: BISHOP, Matthew; KAY, John; MAYER, Colin (Orgs.). Privatization and economic performance. London: Oxford University Press, [s.d.]. p. 299). Tais investimentos foram bastante incentivados por ocasião das privatizações no Reino Unido, inclusive em propagandas do Governo, dentre as quais vale citar, por curiosidade, aquela conhecida como "Tell Sid": Finally, a massive advertising campaign was launched costing over $£ 28$ million pounds in which the public was insistently reminded to tell Sid about the impending share issue. The elusive Sid never actually appeared in these advertisements, but the message was clear enough. As his name alone implied, Sid was one of the millions of ordinary middle-aged or elderly working-class people at whom this share issue was explicitly being targeted. Sid responded magnificently. (SAUNDERS, Peter; HARRIS, Colin. op. cit., p. 15-16).

14 GRAHAM, Cosmo; PROSSER, Tony. Privatising nationalised industries: constitutional issues and new legal techniques. Modern Law Review, Oxford, n. 50, p. 16-51, 1987, p. 31.
} 
Assim, durante o processo de privatizações, o Governo procurou criar mecanismos para neutralizar a vulnerabilidade das antigas empresas estatais. Um desses mecanismos, senão o principal deles, foi justamente a golden share. ${ }^{15}$

Tratava-se de uma ação preferencial resgatável, ${ }^{16}$ com valor nominal de $£ 1.00$, que atribuía ao seu titular - o Estado - prerrogativas especiais. Essas prerrogativas diferiam conforme a empresa a ser privatizada, porém, em geral, consistiam em: ${ }^{17}$ (i) aprovação de reformas estatutárias que tivessem por objeto os artigos relativos à golden share ou aqueles que impusessem limites à titularidade de ações; (ii) veto em deliberações a respeito da dissolução da companhia ou criação de novas ações; e (iii) aprovação da transferência de parte significativa dos ativos da companhia.

Além disso, as golden shares permitiam a adoção de procedimentos específicos para impedir, ou ao menos evitar, nova transferência de controle das companhias privatizadas. Segundo Graham e Prosser, dois procedimentos eram previstos nesse sentido. ${ }^{18} \mathrm{O}$ primeiro deles, utilizado nas privatizações da Britoil e Enterprise Oil, consistia em assegurar ao Estado, por ficção, a maioria dos votos em qualquer deliberação da Assembléia Geral se houvesse (i) apresentação, por qualquer pessoa, de oferta pública de aquisição de ações da companhia privatizada representativas de mais de $50 \%$ do capital votante; ou (ii) possibilidade de exercício, por uma única pessoa ou por diversas pessoas agindo em conjunto, de mais de $50 \%$ dos votos válidos na Assembléia ${ }^{19}$. O segundo procedimento, utilizado com maior freqüência, baseava-se na inclusão, no estatuto social, de regra segundo a qual os administradores da companhia privatizada deveriam adotar determinadas providências caso verificassem que algum acionista era titular de ações

\footnotetext{
${ }^{15} \mathrm{O}$ controle de concentrações empresariais, a permanência do Estado como acionista minoritário da companhia privatizada, a presença de administradores indicados pelo Estado na gestão da companhia, e as supervenientes relações contratuais mantidas entre a empresa privatizada e o Estado também são indicados como instrumentos para atingir essa finalidade. A respeito, vide: GRAHAM, Cosmo; PROSSER, Tony. Privatising nationalised industries... cit., p. 33-49; [s.n.], p. 413-431, 1988. p. 414-419.

${ }^{16}$ Segundo indicam Cosmo Graham e Tony Prosser, na maioria dos casos, operava-se o resgate a requerimento do titular da ação. No entanto, alguns estatutos sociais previam prazo mínimo em que o Estado não poderia resgatar o título (GRAHAM, Cosmo; PROSSER, Tony. Golden shares... cit., p. 413-431, 1988, p. 414-415).

${ }^{17}$ Conforme GRAHAM, Cosmo. Privatization - the United Kingdom experience. Brooklyn Journal of International Law, n. 21, p. 185-211, 1995, p. 196-197; ___ _ PROSSER, Tony. Golden shares... cit., p. 413-431, 1988, p. 414; Privatizing public enterprises... cit., p. 141.

${ }^{18}$ Id. Golden shares... cit., p. 414; e___ ; ___. Privatizing public enterprises... cit., p. 142.

19 Ainda de acordo com Cosmo Graham e Tony Prosser, ao Estado era assegurado também o direito de convocar Assembléias Gerais da companhia e propor qualquer matéria como ordem do dia. Esse direito, aliado ao exercício da maioria dos direitos de voto nas Assembléias Gerais acima referido, garantia ao Estado pleno controle da companhia e dos negócios sociais, em contradição com o próprio processo de privatização. Por essa razão, referidos autores qualificaram o procedimento de "pouco sofisticado" e "incipiente" (Id. Ibid., p. 415; Id. Privatising nationalised industries: constitutional issues and new legal techniques. Modern law review, Oxford, n. 50, p. 16-51, 1987, p. 36).
} 
representativas de mais de $15 \%$ do capital votante. ${ }^{20}$ Em síntese, as providências eram: (i) notificar o acionista para que procedesse à venda das ações em determinado prazo: ${ }^{21} \mathrm{e}$ (ii) em caso de recusa ou atraso por parte do acionista, proceder diretamente à venda das ações. ${ }^{22}$

Sob a justificativa de assegurar proteção ao interesse nacional, as golden shares assim concebidas foram emitidas por diversas companhias no Reino Unido.

Na chamada primeira etapa do programa de privatizações, que ocorreu entre 1979 e 1983, ${ }^{23}$ há notícias da adoção da golden share pelas seguintes companhias: (i) British Aerospace, fabricante de aeronaves civis e militares e de materiais bélicos, privatizada em fevereiro de 1981; ${ }^{24}$ (ii) Cable \& Wireless, prestadora de serviços de telecomunicação, privatizada em três fases, a partir de 1981; (iii) Amersham International, responsável pela fabricação de produtos radioativos para uso em medicina e pesquisa, privatizada em fevereiro de 1982; (iv) Britoil, cujas atividades se concentravam no setor petrolífero, teve suas ações vendidas a partir de novembro de 1982.

Na segunda etapa do programa de privatizações, que se estendeu entre 1984 e $1989,{ }^{25}$ diversas companhias emitiram golden shares, a saber: (i) Sealink, prestadora de

\footnotetext{
${ }^{20}$ Segundo Cosmo Graham e Tony Prosser, por se tratar de regra estatutária, esse procedimento não precisaria estar vinculado a uma golden share, podendo ser encontrado também em companhias que não contavam com esse título, como a British Airways, operadora de linhas aéreas privatizada em janeiro de 1987 (GRAHAM, Cosmo; PROSSER, Tony. Privatizing public enterprises: constitutions, the State and regulation in comparative perspective. New York: Oxford University Press, 1991. p. 142).

${ }^{21}$ Após o recebimento da notificação, as ações nela referidas perdiam o direito de voto e seu respectivo titular não poderia sequer participar das Assembléias Gerais.

${ }^{22}$ Segundo Cosmo Graham e Tony Prosser, tentou-se a aplicação desse procedimento a companhias abertas privadas, que jamais haviam integrado o setor público. No entanto, para os autores, essa aplicação não seria válida, pois referido procedimento contraria o direito societário, notadamente o princípio da livre transferência das ações, e importa a expropriação compulsória da propriedade (GRAHAM, Cosmo; PROSSER, Tony. Golden shares... cit., p. 417; Privatising nationalised industries... cit., p. 37).

${ }^{23}$ Essa etapa caracterizou-se pela ausência de planejamento no processo de privatizações, a ponto de se evitar a referência a um "programa de privatizações", pela transferência, ao setor privado, de empresas estatais que já atuavam em mercados competitivos e pela pequena adesão da população às ofertas de ações. Vide: GRAHAM, Cosmo; PROSSER, Tony. Privatising nationalised industries... cit., p. 17; SAUNDERS, Peter; HARRIS, Colin. op. cit., p. 16-17.

${ }^{24}$ Em fevereiro de 1981, aproximadamente metade da participação estatal no capital da companhia foi transferida a agentes privados. A participação remanescente foi objeto de oferta pública apenas em maio de 1985, juntamente com novas ações emitidas pela companhia. Cf. VICKERS, John; YARROW, George. op. cit., p. 161.

${ }^{25}$ Segundo Peter Saunders e Colin Harris, entre 1984 e 1989 houve a alienação do controle das companhias monopolistas e o aumento da participação da população nas ofertas públicas de venda de ações (SAUNDERS, Peter; HARRIS, Colin. op. cit., p. 17). Note-se, porém, que há divergência entre tais autores e Cosmo Graham e Tony Prosser quanto ao período que corresponderia à segunda, e por conseqüência à terceira, etapa de privatizações. De acordo com esses últimos, a segunda etapa estaria compreendida entre 1984 e 1985 e a terceira teria início no inverno de 1985 (GRAHAM, Cosmo; PROSSER, Tony. Privatising nationalised industries... cit., p. 16-51, 1987, p. 17).
} 
serviços de transporte marítimo, privatizada em $1984 ;{ }^{26}$ (ii) Enterprise Oil, que também atuava no setor petrolífero, privatizada em maio de 1984; (iii) Jaguar, fabricante de automóveis, privatizada em julho de 1984; (iv) British Telecom, prestadora de serviços de telefonia, privatizada em novembro de 1984; (v) British Gas, que atuava no setor de gás natural, privatizada em dezembro de 1986; (vi) Rolls-Royce, cujas atividades se concentravam no setor aeroespacial, aeronáutico e de defesa, privatizada em maio de 1987; (vii) British Airports Authority, responsável pela gestão dos aeroportos no Reino Unido, privatizada em julho de $1987 ;{ }^{27}$ (viii) British Petroleum, indústria petrolífera privatizada em outubro de 1987; ${ }^{28}$ e (ix) British Steel, indústria de aço privatizada em 1988.

Finalmente, na terceira etapa do programa de privatizações, iniciada em $1989,{ }^{29}$ outras companhias passaram a contar com as golden shares, dentre as quais a National Power, geradora de energia, privatizada em 1993, e as prestadoras de serviço de saneamento básico e fornecimento de água.

Como se observa, a golden share foi mecanismo largamente empregado nas privatizações de empresas públicas no Reino Unido. Apesar disso, poucas vezes o Estado invocou as prerrogativas asseguradas pelo título para impedir determinada transferência de ações ou deliberação social. ${ }^{30}$

\footnotetext{
${ }^{26}$ Segundo Nuno Cunha Rodrigues, a golden share emitida pela Sealink assegurava ao Estado a possibilidade de requisitar a frota de navios da companhia em caso de conflitos bélicos. Ainda de acordo com Nuno Cunha Rodrigues, a golden share assim emitida estaria em vigor em 2004 (RODRIGUES, Nuno Cunha. Golden shares - as empresas participadas e os privilégios do Estado enquanto acionista minoritário. Coimbra: Coimbra Editora, 2004. p. 269). Essa informação foi confirmada pelo departamento de relações com consumidores do grupo sueco Stena, que adquiriu o controle acionário da Sealink em 1990. Conforme correspondência eletrônica emitida por aquele departamento em 25.08.05, atualmente o Estado detém uma golden share no capital da sociedade Stena Line Limited.

${ }^{27}$ Em maio de 2003, em sentença que concluiu processo instaurado em 1998, a Corte de Justiça da União Européia considerou a golden share emitida pela British Airports Authority incompatível com o Tratado de Instituição da Comunidade Européia, especialmente com o princípio da livre circulação de capitais. A respeito da sentença, proferida nos autos de número C-98/01 (disponível em: <http://europa.eu.int>. Acesso em: 30 jul. 2005), vide item 2.4. Em setembro de 2003, a golden share foi resgatada (cf. anúncio disponível em: <http:// www.baa.co.uk >. Acesso em: 26 abr. 2006) e em julho de 2004 os estatutos da companhia foram alterados (a respeito, vide OXERA CONSULTING LTD. Special rights of public authorities in privatised EU companies: the microeconomic impact. 2005. Disponível em: <http://www.europa.eu.int/comm/internal_market/capital/ docs/2005_10_special+rights_full_en.pdf $>$. Acesso em: 20 abr. 2006. p. 63).

${ }^{28}$ Conforme explicam John Vickers e George Yarrow, a partir de meados da década de 70, a participação pública na British Petroleum foi reduzida progressivamente, em virtude de sucessivas ofertas de ações feitas pelo governo. Em outubro de 1987 realizou-se a última oferta, que teve por objeto ações representativas de 31,5\% do capital social (VICKERS, John; YARROW, George. op. cit., 161). Por essa razão, há autores que consideram a privatização da British Petroleum anterior a 1987.

${ }^{29}$ A terceira etapa de privatizações teve início com a venda da Regional Water Authorities e caracterizou-se pela ampliação do programa. Segundo Peter Saunders e Colin Harris, a partir de 1989, a privatização tornou-se um fim em si mesmo e passou a atingir também serviços básicos tradicionalmente estatais, como fornecimento de água e de energia elétrica (SAUNDERS, Peter; HARRIS, Colin. op. cit., p. 17).

${ }^{30}$ Como exemplo de uma dessas poucas vezes, Nuno Cobra Rodrigues, Tracey Lloyd e Gavin Robert referem-se ao veto manifestado pelo Estado britânico à oferta pública de aquisição de ações apresentada pela empresa
} 
De fato, na maioria das situações em que o Estado poderia exercer os poderes a ele atribuídos, deixou de fazê-lo. ${ }^{31}$ Dois dos casos mais ilustrativos nesse sentido foram a oferta pública de aquisição de ações apresentada, em 1987, pela British Petroleum à Britoil e a tentativa de aquisição do controle da Jaguar pela Ford e pela General Motors, em 1989.

No primeiro caso, o Estado ameaçou vetar a aquisição, pois ela geraria a concentração das atividades petrolíferas do país, especialmente em relação às reservas do Mar do Norte, então exploradas pela Britoil. Porém, mesmo diante da ameaça de veto, a British Petroleum manteve a oferta pública de aquisição de ações. Ao final das negociações, o Estado e a British Petroleum alcançaram um acordo, mediante o qual o primeiro se comprometeu a não impedir a aquisição e a considerar o resgate da golden share em breve, e a British Petroleum comprometeu-se a não demitir empregados e não alienar ativos de titularidade da Britoil. Tratou-se de mero acordo político, não vinculativo, que acabou por ser descumprido pela British Petroleum, sem que qualquer sanção lhe fosse imposta. ${ }^{32}$

No segundo caso, a golden share atribuía ao Estado, até 1990, o poder de impedir que qualquer acionista exercesse direitos de voto correspondentes a mais de $15 \%$ do capital votante. Embora desde 1988 a Ford já tivesse manifestado interesse na aquisição de participação acionária na Jaguar, no início de 1989 a administração dessa última entrou em negociações com a General Motors, que tinha a intenção de adquirir participação minoritária relevante na companhia. No final de 1989, as administrações da Jaguar e da General Motors já haviam inclusive firmado Memorando de Entendimentos a respeito do negócio e estava em vias de elaboração o documento, mediante o qual a aquisição da participação seria proposta aos acionistas da Jaguar. Paralelamente a isso, a Ford noticiou a Securities and Exchange Comission, no final de outubro de 1989, que pretendia apresentar oferta pública de aquisição das ações de emissão da Jaguar, desde que o Estado abdicasse de exercer as prerrogativas inerentes à golden share. Na véspera da data prevista para o anúncio da oferta pública planejada pela Ford, o Secretário de Estado para o Comércio e a

americana Southern Company à National Power (RODRIGUES, Nuno Cunha. Golden shares: as empresas participadas e os privilégios do Estado enquanto acionista minoritário. Coimbra: Coimbra Editora, 2004. p. 269; e LLOYD, Tracey; ROBERT, Gavin. Golden shares and European law. European Counsel, London, n. 2, fasc. 10, p. 37-40, 1998, p. 38).

31 Conforme notam SODI, Jacopo. op. cit., p. 376 e SANTONASTASO, Felice. Le società di interesse nazionale. Milano: Dott. A. Giuffrè Editore, 2002. p. 182, mais do que mecanismo para impedir aquisições de controle das companhias privatizadas no Reino Unido, a golden share era utilizada pelo Estado como instrumento de negociação com as partes envolvidas. Essa estratégia pode ser verificada com clareza no caso British Petroleum/Britoil, comentado a seguir.

32 Para uma descrição detalhada do caso, vide GRAHAM, Cosmo; PROSSER, Tony. Privatizing public enterprises... cit., p. 144-147; RUTABANZIBWA, Audax Peter. What is golden in the golden share? Company law implications of privatisation. Company Lawyer, London, n. 17, fasc. 2, p. 40-45, 1996, p. 44; e SANTONASTASO, Felice. op. cit., p. 181-183. 
Indústria veio a público e declarou que, caso acionistas que representassem $75 \%$ do capital social da Jaguar estivessem de acordo, o Estado estaria disposto a renunciar ao exercício dos direitos que lhe eram garantidos pela golden share. Essa manifestação teve por efeito imediato a elevação do valor das ações de emissão da Jaguar. Em virtude dessa elevação, a General Motors perdeu interesse na aquisição antes negociada com a administração da Jaguar, o que fez com que o Conselho de Administração dessa companhia recomendasse aos acionistas da Jaguar a aceitação da oferta pública feita pela Ford. ${ }^{33}$

Não-obstante o raro exercício pelo Estado dos poderes inerentes às golden shares e os questionamentos havidos no âmbito da União Européia, diversas companhias britânicas contam, ainda hoje, com o mecanismo. A título exemplificativo, vale citar: ${ }^{34}$ BAE Systems plc, sucessora da British Aerospace, ${ }^{35}$ e Rolls-Royce Group plc. ${ }^{36}$

${ }^{33}$ A respeito do caso e das possíveis motivações do Estado, confira-se GRAHAM, Cosmo; PROSSER, Tony. Privatizing public enterprises: constitutions, the State and regulation in comparative perspective. New York: Oxford University Press, 1991. p. 148-149.

${ }^{34}$ Embora RODRIGUES, Nuno Cunha. Golden shares: as empresas participadas e os privilégios do Estado enquanto acionista minoritário. Coimbra: Coimbra Editora, 2004. p. 270 indique que, em 2001, doze empresas privatizadas no Reino Unido ainda apresentaram uma golden share em seu capital social - como a British Gas e a National Power - em muitas delas o Estado já havia procedido ao resgate da ação. É justamente o caso da BG plc, sucessora da British Gas, em que o resgate ocorreu em 2000 (cf. Relatório Anual da companhia, referente ao exercício de 2004 (disponível em: <http://www.ir.bg-group.com>. Acesso em: 25 ago. 2005), e a International Power, nova denominação da National Power, em que o resgate datou de agosto de 2000 (cf. Relatório Anual da companhia, referente ao exercício de 2004 (disponível em $<$ http://ipplc.com>. Acesso em: 25 ago. 2005). Segundo relatório da Comissão Européia datado de julho de 2005, além de deter golden shares na BAE Systems e na Rolls Royce, o Reino Unido ainda é titular de prerrogativas especiais na Devonport Dockyard (European Commission. Special rights in privatised companies in the enlarged union: a decade full of developments. Commission Staff working document. 22 July 2005. Disponível em: $<\mathrm{http}: / /$ ec.europa. eu/internal_market/capital/docs/privcompanies_en.pdf $>$. Acesso em: 17 abr. 2006, p. 18)

${ }^{35}$ Conforme item 23 do Relatório Anual da companhia, referente ao exercício de 2004 (disponível em: <http:// www.baesystems.com>. Acesso em: 25 ago. 2005). De acordo com esse item, certos dispositivos do estatuto social da companhia não podem ser alterados sem o consentimento do titular da "special share", i.e., o Estado, na pessoa do Secretário do Comércio e da Indústria. Dentre tais dispositivos, estão aqueles que prevêem que: (i) nenhum estrangeiro, isoladamente ou em conjunto, pode deter participação superior a $15 \%$ do capital social; (ii) os membros do Conselho de Administração, em sua maioria, devem ser britânicos; (iii) os principais Diretores da companhia (Executive e qualquer Executive Chairman) devem ser cidadãos britânicos. Por fim, é assegurado ao Secretário do Comércio da Indústria o direito de ser convocado e de comparecer a qualquer Assembléia Geral da companhia. Porém, salvo se a matéria vincular-se à special share, a ele não é atribuído direito de voto.

${ }^{36}$ Conforme item 25 do Relatório Anual da companhia, referente ao exercício de 2004 (disponível em: <http:// www.rolls-royce.com>. Acesso em: 25 ago. 2005). Segundo o art. 11 do estatuto social da companhia - obtido junto ao departamento de relações com investidores em 26.08.05 - são direitos do Estado britânico, na qualidade de titular da "special share": (i) aprovar a alteração de determinados dispositivos do estatuto social, dentre os quais aqueles referentes a (a) direitos da special share; (b) proibição de aquisição, por estrangeiros, de mais de $15 \%$ dos direitos de voto da companhia; (c) obrigatoriedade de nacionalidade britânica para os principais Diretores da companhia (Chairman e Chief Executive) e para metade dos membros dos órgãos de administração; (ii) aprovar proposta de dissolução ou liquidação da companhia; (iii) aprovar previamente qualquer forma de disposição dos ativos da divisão nucelar do grupo Rolls-Royce ou de ativos do grupo em geral, salvo em caso de transferência desses ativos entre empresas do próprio grupo; (iv) ser convocado 


\subsection{França}

Na França, a chamada action spécifique foi originalmente instituída pela Lei n. 86.912 , de 6 de agosto de $1986,{ }^{37}$ durante a primeira etapa do programa de privatizações das empresas integrantes do setor público francês. ${ }^{38}$

De acordo com o disposto no art. 10, alínea 2, da Lei n. 86.912, caberia ao ministro da Economia definir se, em determinado processo de privatização, a proteção ao interesse nacional demandaria a criação de uma action spécifique. Ainda segundo esse artigo, tal action seria criada por ato ministerial (arrêté du ministre ${ }^{39}$ ), mediante a conversão de uma ação ordinária detida pelo Estado francês no capital social da companhia sujeita à privatização, ${ }^{40}$ e vigoraria pelo prazo de cinco anos, salvo se o ministro da Economia determinasse, antecipadamente, sua conversão em ação ordinária (cf. alínea 5 do mesmo art. 10).

e comparecer a Assembléias Gerais da companhia, porém, nesse caso, sem exercício de direito de voto nas matérias alheias à special share.

37 Trata-se da lei que disciplinava o procedimento e as medidas a serem adotadas para a alienação da participação estatal a agentes privados, alienação essa previamente autorizada pela Lei n. 86-793, de 2 de julho de 1986. Cumpre mencionar que, em junho de 1986, o Conselho Constitucional francês declarou, na decisão de n. 86-207, a constitucionalidade do projeto que originou a Lei n. 86-793 (disponível em: <http://www.conseilconstitucionnel.fr/decision/1986/86207dc.htm>. Acesso em: 11 mar. 2005). Sobre essa decisão, vide PEZARD, Alice. L' action spécifique des sociétés privatisées. Droit et Pratique du Commerce International, Paris, t. 19, n. 3, p. 523-534, 1993. p. 524-525.

38 A primeira etapa do programa de privatizações francês ocorreu entre 1986 e 1988, com o duplo objetivo de reduzir o déficit público e promover o desenvolvimento do mercado de valores mobiliários no país através do chamado capitalisme populaire (definido, em linhas gerais, conforme anteriormente mencionado, como dispersão acionária decorrente da realização de pequenos investimentos individuais por parte da população). Essa etapa do programa de privatizações caracterizou-se pelo êxito das alienações de numerosas participações estatais, dentre as quais se destacam as detidas nas empresas Paribas e Saint-Gobain. Porém, em virtude da crise no mercado de valores mobiliários em outubro de 1987, o programa de privatizações foi interrompido. Em 1988, a adoção por François Mitterand da chamada política "ni-ni” - "ni nouvelles privatisations, ni nouvelles nationalisations" - impediu a retomada desse programa, ao menos formalmente. Na prática, segundo Hervé Dumez e Alain Jeunemaitre, a política "ni-ni" foi flexibilizada para permitir o financiamento das empresas estatais (DUMEZ, Hervé; JEUNEMAITRE, Alain. Les privatisations en France, 1986-1992. In: WRIGHT, Vincent (Org.). Les privatisations en Europ: programmmes et problèmes. [s.1.]: Actes Sud, 1993. p. 127).

39 Trata-se de “décision exécutoire à portée générale ou individuelle émanant d'un ou de plusieurs ministres (arrêté ministériel ou interministériel) ou d'autres autorités administratives (arrêté préfectoral, municipal, etc.)". Cf. GUILLIEN, Raymond; MONTAGNIER, Gabriel. Lexique des termes juridiques. 13. ed. Paris: Dalloz, 2001. p. 45.

40 Embora a criação da action spécifique por meio de ato ministerial (arrêté) produzisse efeitos desde logo, os estatutos sociais da companhia deveriam ser reformados para contemplar os poderes e as características desse novo título acionário (cf. alínea 3 do art. 10 da Lei n. 86-912). Importante notar que essa reforma deveria ser realizada antes da avaliação da empresa pela Comissão de Privatização, que é evidentemente alterada pela adoção da action spécifique. Sobre o efeito da reforma estatutária sobre a avaliação da companhia, confirase: PÉzArd, Alice. L'action spécifique des sociétés privatisées. Droit et Pratique du Commerce International, Paris, t. 19, n. 3, p. 523-534, 1993. p. 526. 
A action spécifique, assim instituída, atribuía ao Estado a prerrogativa de aprovar previamente a participação, na companhia, de pessoas ou grupo organizado de pessoas titulares de ações representativas de mais de 10\% do capital social (cf. alínea 4 do art. 10 da Lei n. 86.912). Na hipótese de o ministro da Economia negar tal aprovação, as ações em questão seriam privadas do direito de voto e seus respectivos titulares estariam obrigados a aliená-las no prazo de 3 (três) meses. Se esse prazo não fosse observado, seria determinada a venda forçada das ações, segundo as condições previstas em decreto (cf. alínea 7 do mesmo dispositivo).

Sob esse formato, e, portanto, durante a chamada primeira etapa do programa de privatizações francês, a action spécifique foi adotada em poucas companhias, especificamente: Société National Elf-Aquitaine, ${ }^{41}$ principal companhia no setor de energia francês, Compagnie des Machines Bull, ${ }^{42}$ que atuava no ramo de informática; Agence Havas, ${ }^{43}$ que atua no ramo de comunicações e publicidade; e Société Matra, cujas atividades se concentravam no setor aeroespacial. ${ }^{44}$

Ainda a respeito da configuração da action spécifique, durante a primeira etapa do programa de privatizações francês, cumpre mencionar que, em 4 de julho de 1989, o Conselho Constitucional francês proferiu decisão favorável à adoção do mecanismo. Nessa decisão, de n. 89.254, o Conselho declarou que a prerrogativa de aprovar a participação de pessoas ou grupo organizado de pessoas titulares de ações representativas de mais de $10 \%$ do capital social - atribuída ao titular da action spécifique - não contrariava os princípios constitucionais da liberdade de iniciativa e da igualdade, nem violava o direito de propriedade. ${ }^{45}$

${ }^{41}$ Confira-se, nesse sentido, o “Arrêté ministériel du 15.09.1986”, publicado no Journal Officiel de la République Française, seção Lois et Décrets, em 16 de setembro de 1986 (extrato disponível em: <http://www.legifrance. gouv.fr>. Acesso em: 03 maio 2005). Segundo Georges Ripert e René Roblot, a action spécifique foi adotada na Societé National Elf Aquitaine já na primeira etapa do programa de privatização francês, embora nessa etapa apenas $11 \%$ de seu capital - e não a maioria dele - tenha sido transferido ao setor privado (Traité de droit commercial. 17. ed. Paris: L.G.D.J., 1998. t. I, p. 1538). Para Alice Pézard, não se tratou de própria privatização, mas de uma "operation de respiration" (L' action spécifique des sociétés privatisées. Droit et Pratique du Commerce International, Paris, t. 19, n. 3, p. 523-534, 1993, p. 526).

${ }^{42} \mathrm{Na}$ Compagnie des Machines Bull, a action spécifique foi instituída pelo "Arrêté ministériel du 03.03.1987", publicado no Journal Officiel de la République Française, seção Lois et Décrets, em 05 de março de 1987 (extrato disponível em: $<\mathrm{http}: / /$ www.legifrance.gouv.fr>. Acesso em: 03 maio 2005).

${ }^{43} \mathrm{Na}$ Agence Havas, a action spécifique foi instituída pelo "Arrêté ministériel du 30.03.1987", publicado no Journal Officiel de la République Française, seção Lois et Décrets, em 02 de abril de 1987 (extrato disponível em: $<\mathrm{http}: / /$ www.legifrance.gouv.fr>. Acesso em: 01 abr. 2005).

44 Na Societé Matra, a action spécifique foi instituída pelo "Arrêté ministériel du 08.09.1987", publicado no Officiel de la République Française, seção Lois et Décrets, em 10 de setembro de 1987 (extrato disponível em: $<$ http://www.legifrance.gouv.fr>. Acesso em: 14 abr. 2005).

45 Sobre essa decisão, cujo inteiro teor está disponível em: $<\mathrm{http}: / /$ www.conseil-constitutionnel.fr $>$. Acesso em: 10 mar. 05, vide: PEZARD, Alice. L' action spécifique des sociétés privatisées. Droit et Pratique du Commerce International, Paris, t. 19, n. 3, p. 523-534, 1993. p. 531; e . The golden share of privatized companies. Brooklyn Journal of International Law, New York, n. 21, p. 85-95, 1995. p. 93-94. 
Em 1993, com a edição da Lei n. 93-923, iniciou-se a segunda etapa do programa francês de privatizações. Embora tenha respeitado os princípios e objetivos da Lei n. 86-912, ${ }^{46}$ essa lei alterou a disciplina de certos mecanismos criados pela norma anterior, dentre os quais a action spécifique.

Segundo o art. $7^{\circ}$ da Lei n. 93.923, que atribuiu nova redação ao art. 10 da Lei n. 86.912, a action spécifique passaria a ser instituída por decreto (décret) e não mais por arrêté du ministre. Nesse decreto, seriam determinados os direitos da action em apreço, que poderiam consistir em: (i) aprovação prévia, pelo ministro da Economia, da participação de pessoas ou grupo organizado de pessoas no capital social da companhia privatizada, cabendo ao próprio decreto fixar o percentual de participação que ensejava o exercício desse direito; ${ }^{47}$ (ii) nomeação de um ou dois membros do Conselho de Administração ou do Conselho Fiscal da companhia, indicados no próprio decreto, que porém não teriam direito de voto; e (iii) veto nas deliberações que envolvessem cessão ou oneração de ativos da companhia, capazes de atentar contra os interesses nacionais, veto esse que poderia ser exercido segundo procedimento previsto no Decreto n. $93.1296 .^{48}$

Como se pode notar, a Lei n. 93.923 ampliou significativamente o rol dos direitos atribuídos ao Estado em função da detenção da action spécifique. Além disso, a referida lei deixou de prever prazo para vigência do título, dispondo, ao invés, que a action spécifique poderia ser convertida em ação ordinária a qualquer tempo, salvo se, com tal medida, a independência nacional pudesse restar comprometida.

\footnotetext{
${ }^{46}$ Segundo Dominique Carreau e Robert Treuhold, a Lei n. 93.923, embora com algumas diferenças qualitativas, caracterizou-se pela continuidade do programa instituído pela Lei n. 86.912, em diversos aspectos: (i) estrutural, já que somente modificou a lei anterior, não a revogou; (ii) finalístico, pois os objetivos visados permaneceram o desenvolvimento do capitalismo popular, a participação dos assalariados nas empresas em que trabalhavam, e a defesa dos interesses nacionais; e (iii) procedimental, na medida em que foram mantidos os métodos de privatização já previstos na lei anterior (CARREAU, Dominique; TREUHOLD, Robert. Le nouvelle loi de privatisation ou l'annonce prématurée de la mort de Colbert. Recueil Dalloz: chroniques, Paris, n. 32, p. 231-235, 1993). Ainda sobre as alterações promovidas pela Lei n. 93.923, vide: BORDE, Dominique; PONCELET, Aline. Le noveau programme de privatisation français de 1993: une importante evolution des techniques de mise en vente sur les marchés financiers. Rivista delle Società, Milano, n. 39, fasc. 1-2, p. 269-302, genn./apr. 1994; e MARCHETTI, Piergaetano. Le privatizzazioni in Francia. Rivista delle Società, Milano, n. 39, fasc. 1-2, p. 264-268, genn./apr. 1994; REINHARD, Yves. Privatisation des enterprises. Revue Trimestrielle de Droit Commercial et de Droit Économique, Paris, n. 4, p. 670-673, oct./déc. 1993.

${ }^{47}$ As conseqüências para as chamadas participações irregulares, i.e., aquelas que não contaram com a aprovação do Ministro da Economia, permaneceram as mesmas da Lei n. 86.912, a saber: perda do direito de voto e obrigatoriedade de cessão dos títulos em um prazo de 3 meses. Na hipótese de não realização dessa cessão, proceder-se-ia à venda forçada das ações (cf. alínea III do art. 10 da Lei n. 86.912, com redação modificada pela Lei n. 93.923).

${ }^{48}$ Segundo esse decreto, a pretendida cessão ou oneração de ativos deveria ser informada ao Ministro da Economia, que teria prazo de um mês, prorrogável por 15 dias, para se opor, mediante publicação de arrêté. $\mathrm{Na}$ ausência de manifestação nesse prazo, a operação seria considerada autorizada. Texto integral do decreto disponível em: <http://www.legifrance.gouv.fr>. Acesso em: 11 mar. 2005.
} 
No regime da Lei n. 93.923, poucas companhias contaram com uma action spécifique, dentre as quais se podem citar a própria Société National Elf-Aquitaine, acima referida, Thomson S.A., Thomson CSF e Société Aerospatiale.

A Societé National Elf-Aquitaine foi integralmente privatizada em 1993. Para assegurar a proteção aos interesses nacionais, a action spécifique garantia ao Estado francês todas as prerrogativas previstas em lei, nos seguintes termos: (i) direito de aprovar, previamente, a aquisição de títulos representativos de 1/10,1/5 ou 1/3 do capital social total da companhia ou de seu capital votante; (ii) direito de nomear dois representantes para o Conselho de Administração da Sociedade, sendo um indicado pelo ministro da Economia e outro pelo ministro da Energia; (iii) direito de opor-se à cessão ou oneração das participações societárias majoritárias detidas pela companhia nas seguintes sociedades Elf-Aquitaine Production, Elf-Antar France, Elf-Gabon S.A. e Elf-Congo S.A. ${ }^{49}$

Essas prerrogativas, porém, nem sempre foram exercidas pelo Estado francês. Em 1999, o Estado absteve-se de exercê-las para impedir a compra da Elf Aquitaine pelo grupo TotalFina, que havia apresentado uma oferta pública de aquisição do controle acionário da companhia. ${ }^{50}$ Tal abstenção foi a alternativa política encontrada pelo Governo francês, em vista dos questionamentos feitos à época pela Comissão da Comunidade Européia quanto à adequação da action spécifique ao Tratado de Instituição da Comunidade.

De fato, também em 1999 foi instaurado, perante a Corte de Justiça da Comunidade Européia, o processo n. C-483/99, que tinha por objeto a compatibilidade da action spécifique detida pelo Estado francês no capital da Societé Elf Aquitaine com o princípio da livre circulação de capitais inscrito no art. 56 do Tratado de Instituição da Comunidade Européia. Esse processo foi concluído, em junho de 2002, com decisão desfavorável à França. Nessa decisão, a Corte de Justiça declarou que a adoção da action spécifique pelo Estado francês implicava violação ao Tratado. Em outubro de 2002, como conseqüência direta dessa sentença, o Decreto n. 93.1298, que instituiu a action spécifique na Societé Elf Aquitaine, foi revogado. ${ }^{51}$

Por sua vez, a Thomson S.A. e a Thomson CSF, integrantes do mesmo grupo econômico, tinham como atividade principal a industrialização de produtos

\footnotetext{
${ }^{49}$ Conforme Decreto n. 93.1298, de 13 de dezembro de 1993, originalmente publicado no Journal Officiel de la République Française n. 289, de 14 de dezembro de 1993, e republicado no Journal Officiel de la République Française n. 299, de 26 de dezembro de 1993. A íntegra de ambas publicações encontra-se disponível em: $<$ http://www.legifrance.gouv.fr>. Acesso em: 10 mar. 2005.

${ }^{50}$ A respeito, confira-se SAntonastaso, Felice. Le società di interesse nazionale. Milano: Dott. A. Giuffrè Editore, 2002. p. 44 e 45, 141 e 142.

51 A revogação ocorreu por força do Decreto n. 2002-1231, de 03 de outubro de 2002, originalmente publicado no Journal Officiel de la République Française n. 233, de 05 de outubro de 2002, cuja íntegra está disponível em: <http://www.legifrance.gouv.fr>. Acesso em: 10 mar. 2005.
} 
eletrônicos utilizados no setor de defesa da França, como radares. Assim, invocando a proteção da segurança nacional do país, o Governo francês criou, em agosto de 1996, uma action spécifique na Thomson S.A., com os seguintes direitos: (i) aprovação prévia de qualquer aquisição de títulos representativos de 1/10 do capital ou dos direitos de voto da companhia; (ii) nomeação de um membro do Conselho de Administração da sociedade; e (iii) veto em caso de cessão ou oneração de determinadas participações majoritárias detidas pela companhia. ${ }^{52}$

Em março de 1997, porém, tal action foi extinta, em função de alteração na política de privatizações francesa. ${ }^{53}$ Conforme descreve Santonastaso, ${ }^{54}$ o Governo Jospin preferiu iniciar a transferência do controle do grupo Thomson ao setor privado pela venda das ações representativas do capital social da Thomson CSF e não mais da Thomson S.A.. Essa venda também foi precedida pela instituição de uma action spécifique cujos direitos, semelhantes aos atribuídos ao Estado na Thomson S.A., eram os seguintes: (i) aprovação prévia de qualquer aquisição de títulos representativos de 1/10 ou múltiplos de 1/10 do capital ou dos direitos de voto da companhia; (ii) nomeação de um membro do Conselho de Administração da sociedade; e (iii) veto em caso de cessão ou oneração de determinadas participações majoritárias detidas pela companhia. ${ }^{55}$ Embora Rodrigues $^{56}$ indique que tal action spécifique teria sido convertida em ação ordinária, não há notícia da edição de norma que tenha operado essa conversão. ${ }^{57}$

Por fim, na Société Aerospatiale, cujas atividades no setor aeroespacial também estavam vinculadas à defesa da França, a action spécifique foi criada, em 1999, para "proteger os interesses essenciais da segurança nacional". Os poderes por ela atribuídos ao Estado eram idênticos àqueles previstos na Thomson CSF, descritos acima. No entanto, o veto recaía não apenas sobre a cessão ou oneração de participações majoritárias em sociedades controladas, mas também dos bens e direitos relativos à capacidade de controle de produção e a fabricação e montagem de mísseis balísticos. ${ }^{58}$ Em 2000, por ocasião da

\footnotetext{
${ }^{52}$ Cf. Decreto n. 96.689, de 02 de agosto de 1996, publicado no Journal Officiel de la République Française $n$. 180, de 03 de agosto de 1996, cuja íntegra está disponível em: <http://www.legifrance.gouv.fr>. Acesso em: 10. mar. 2005.

53 A extinção ocorreu por força do art. 1 do Decreto n. 97.190, abaixo referido, que revogou o Decreto n. 96.689.

54 SANTONASTASO, Felice. op. cit., p. 144-151.

55 Tais direitos estavam previstos no Decreto n. 97.190, de 04 de março de 1997, originalmente publicado no Journal Officiel de la République Française n. 54, de 05 de março de 1997. Íntegra disponível em: <http:// www.legifrance.gouv.fr>. Acesso em: 10 mar. 2005.

${ }^{56}$ RODRIGUES, Nuno Cunha. op. cit., p. 280.

${ }^{57}$ Inclusive segundo informações obtidas, em janeiro de 2006, em <http://www.legifrance.gouv.fr>, o Decreto n. 97.190 permanece em vigor.

58 Conforme Decreto n. 99-97, de 15 de fevereiro de 1999, originalmente publicado no Journal Officiel de la République Française n. 39, de 16 de fevereiro de 1999. Íntegra disponível em: < http://www.legifrance.gouv. fr>. Acesso em: 09 maio 2005.
} 
constituição da European Aeronautic Defense and Space Company EADS NV - sociedade formada pelo agrupamento das atividades de diversas empresas européias que atuavam no setor aeroespacial - essa action foi convertida em ação ordinária. ${ }^{59}$

Como se observa, tanto na primeira, quanto na segunda etapas do programa de privatização francês, a action spécifique foi mecanismo de defesa dos interesses nacionais pouco utilizado.

Alguns autores apontam como justificativa para essa circunstância a existência, no ordenamento francês, de outros instrumentos aptos a alcançar os mesmos objetivos visados pela action spécifique, em especial os chamados noyaux durs. ${ }^{60}$ Tratase, conforme indica a própria nomenclatura, de núcleos formados por acionistas titulares de significativo número de ações ${ }^{61}$ que se comprometem, por acordo de acionistas, a manter a titularidade dessas ações durante determinado tempo, garantindo, dessa forma, a estabilidade da estrutura de capital da companhia privatizada. ${ }^{62}$

A par da existência de tais mecanismos, o limitado alcance da action spécifique na França pareceu decorrer, também, dos questionamentos acerca de sua licitude, havidos tanto no âmbito da Comunidade Européia quanto dentre os juristas do próprio país.

\subsection{Itália}

Na Itália, a reserva das prerrogativas estatais nas empresas objeto de privatização foi assegurada, em 1994, pelos chamados poteri speciali, previstos no

\footnotetext{
${ }_{59}$ A conversão ocorreu por força do Decreto n. 2000-630, de 07 de julho de 2000, originalmente publicado no Journal Officiel de la République Française n. 157, de 08 de julho de 2000, cuja íntegra está disponível em: $<$ http://www.legifrance.gouv.fr >. Acesso em: 10 mar. 2005.

${ }^{60}$ Dentre tais autores, vide GRAHAM, Cosmo; PROSSER, Tony. Privatizing public enterprises... cit., p. $154-$ 160; e SODI, Jacopo. op. cit., p. 376 e 377.

${ }^{61}$ Segundo Piergaetano Marchetti, a constituição de tais núcleos só foi possível em virtude do disposto no art. 4. da Lei n. 86.912, modificada pela Lei n. 93.923. De acordo com esse artigo, embora, em regra, a alienação das participações estatais devesse ocorrer de acordo com os procedimentos do mercado financeiro, o Ministro da Economia poderia prospectar um ou mais adquirentes fora do mercado (MARCHETTI, Piergaetano. Le privatizzazioni in Francia. Rivista delle Società, Milano, n. 39, fasc. 1-2, p. 264-268, genn./apr. 1994. p. 265). Conforme relata Patrick Terroir, esses adquirentes pagavam preço inferior - com desconto de $5 \%$ a $20 \%$ - em relação ao fixado pela Comissão de Privatização (Contra as ondas de estatização. In: PIRIE, Madsen et al. Privatização, mercado de capitais e democracia: a recente experiência internacional. Sem referência ao tradutor. Rio de Janeiro: Correio da Serra, 1988. p. 132).

${ }^{62}$ A respeito da definição dos noyaux durs, confira-se RIPERT, Georges; ROBLOT, René. Traité de droit commercial. 17. ed. Paris: L.G.D.J., 1998. t. I, p. 1538. Sobre a utilização dos noyaux durs no programa de privatização francês, vide DURUPTY, Michel. Le privatizzazioni in Francia. Rivista Trimestrale di Diritto Pubblico, Milano, n. 1, p. 44-85, 1988, p. 78-83.
} 
Decreto-Lei n. 332, de 31 de maio de 1994, ${ }^{63}$ convertido, com alterações, ${ }^{64}$ na Lei n. 474, de 30 de julho de $1994 .^{65}$

Diversamente do que se observou no Reino Unido, com a golden share, e na França, com a action spécifique, a atribuição ao Estado italiano de tais poteri speciali não dependia da titularidade de ações representativas do capital social da companhia privatizada. $^{66}$

Segundo o art. 2, comma 1, do Decreto-Lei n. 332, previamente à transferência de seu controle acionário a particulares, as empresas públicas atuantes nos setores de defesa, transporte, telecomunicações, energia e outros serviços públicos poderiam ser submetidas à reforma estatutária com o objetivo de introduzir, no respectivo estatuto social, cláusula acerca dos poteri speciali. Ainda de acordo com esse dispositivo, caberia ao presidente do Conselho de Ministros determinar, em decreto, quais sociedades estariam sujeitas a tal reforma.

Competiria, porém, ao ministro da Fazenda, ouvidos alguns outros ministros, especificar, em decreto, os poderes que se pretendia assegurar ao Estado ${ }^{67}$, dentre os

\footnotetext{
${ }^{63}$ Como noticiam (JAEGER, Pier Giusto. Privatizzazioni; "public companies"; problemi societari. Giurisprudenza Commerciale, Milano, n. XXII, parte I, fasc. 1, p. 5-19, 1995. p. 5) e (SODI, Jacopo. Poteri speciali, golden share e false privatizzazioni. Rivista delle Società, Milano, n. 41, fasc. 2-3, p. 368-404, mar./ giugno 1996. p. 380), o Decreto-Lei n. 332 sucedeu diversos decretos-lei que perderam eficácia por ausência de conversão em lei no prazo de 60 dias a contar da data da respectiva publicação, prazo esse previsto no art. 77 da Constituição da República Italiana (disponível em: <http://www.cortecostituzionale.it>. Acesso em: 11 jul. 2005. Referência é feita aos seguintes: Decreto-Lei n. 389, de 27 de setembro de 1993; Decreto-Lei n. 486, de 28 de novembro de 1993; Decreto-Lei n. 75, de 31 de janeiro de 1994; e Decreto-Lei n. 216, de 31 de março de 1994 (todos disponíveis em: <http://www.normeinrete.it>. Acesso em: 11 jul. 2005).

${ }^{64}$ A respeito dessas alterações, que serão mencionadas a seguir conforme sua relevância, vide MARCHETTI, Piergaetano. Le privatizzazioni in Italia: la legge 474/1994 e ulteriori documenti. Rivista delle Società, Milano, n. 39, fasc. 4, p. 748-764, luglio/ag. 1994.

65 Interessante notar que a Corte Constitucional da República Italiana autorizou, por meio da sentença n. 29, de 1997, a realização de referendum popular para apreciar a manutenção da vigência do artigo da lei relativo aos poteri speciali (inteiro teor da sentença disponível em: <http://www.giucost.org/decisioni/1997/0029s97.htm>. Acesso em: 06 jun. 2005). Porém, esse referendum, designado "per abolizione dei poteri speciali riservati al Ministro del Tesoro nelle aziende privatizzate", não atingiu o quorum necessário para a validade da consulta (cf. DI PORTO, Fabiana. Note sul regime giuridico delle privatizzazioni in Italia. In particolare nei servizi pubblici essenziali. Giurisprudenza Commerciale, Milano, n. XXVII, parte I, fasc. 6, p. 738-767, 1999. p. 761).

${ }_{66}$ Alguns autores indicam, porém, que a Itália pretendia adotar mecanismo de intervenção estatal vinculado à participação acionária. Tratava-se da chamada azione a diritto privilegiato, prevista no projeto de Lei n. 3971, de 1986. No entanto, tal opção foi abandonada a partir da Delibera CIPE (Comitato Interministeriale per la Programmazione Economica) n. 96, de 30 de dezembro de 1992, que tratou, em seu item 11, da reserva ao Estado de "diritti speciali" somente em virtude de previsão estatutária (inteiro teor disponível em: $<\mathrm{http}: / /$ www.cipecomitato.it $>$. Acesso em: 20 jul. 2005 e transcrito em MARCHETTI, Piergaetano (Org.). Le privatizzazioni in Italia: saggi, leggi e documenti. Milano: Dott. A. Giuffrè Editore, 1995. p. 62-66). A respeito da azione di diritto privilegiato e da Delibera CIPE, vide DEL CASALE, Enrica. Uno strumento diretto di controllo governativo sulle privatizzazioni: le "golden shares". Politica del Diritto, Bologna, n. 1, p. 149-157, mar. 1988. p. 155-157; DI PORTO, Fabiana. op. cit., p. 751; e SODI, Jacopo. op. cit., p. 378-379.

67 Vide art. 1-bis, inserido no Decreto-Lei n. 332 por ocasião de sua conversão na Lei n. 474.
} 
seguintes: (i) direito de aprovar previamente (gradimento) a aquisição de participação relevante na companhia a ser privatizada, participação essa correspondente a pelo menos 5\% do capital votante (cf. alínea "a" do art. 2, comma 1, do Decreto-Lei n. 332); (ii) direito de aprovar a celebração de acordos ou pactos para-sociais que envolvessem ações com direito a voto representativas de, no mínimo, 5\% do capital votante (cf. alínea "b" do mesmo dispositivo); (iii) veto nas deliberações que tivessem por objeto a dissolução, cisão ou fusão da companhia, a transferência de estabelecimento empresarial, a mudança da sede social para o Exterior, a alteração do objeto social e a modificação da cláusula estatutária relativa aos poteri speciali (cf. alínea "c" do art. 2, comma 1, do Decreto-Lei n. 332); ${ }^{68}$ (iv) eleição de no mínimo um administrador da companhia, observado o limite de um, quarto dos membros do Conselho de Administração, e de um membro do Conselho Fiscal (cf. alínea "d" do mesmo dispositivo). ${ }^{69}$

Segundo o disposto no decreto-lei, os poteri speciali estatutariamente previstos seriam atribuídos ao ministro da Fazenda que os deveria exercer em conjunto com outros ministros, tendo em vista os objetivos nacionais de política econômica e industrial. ${ }^{70}$

Ao abrigo dessa disciplina, os poteri speciali foram contemplados no estatuto social das companhias Eni s.p.a., cujas atividades se concentram no setor energético e petroquímico, Stet s.p.a. - Società Finanziaria Telefonica e Telecom Italia s.p.a., prestadoras de serviços de telecomunicações.

Na Eni s.p.a., primeira sociedade italiana privatizada a adotar tal mecanismo, ${ }^{71}$ foram reservados ao Estado todos os poteri speciali previstos no art. $2^{\circ}$, comma 1 , do decreto-lei n. 332. De fato, segundo o item 6.2 do estatuto social da companhia, ${ }^{72}$ o ministro

\footnotetext{
${ }^{68}$ Aos acionistas dissidentes da deliberação que aprovasse a introdução dessa prerrogativa no estatuto social era assegurado direito de retirada, nos termos do art. 2, comma 2, do Decreto-Lei n. 332.

${ }^{69}$ Cumpre notar que o direito de eleger administradores e membro do Conselho Fiscal, previsto nesta alínea, já era assegurado ao Estado pelo Código Civil italiano, em seus arts. 2.458 e 2.459, vigentes até a reforma implementada em 2003. Sobre o assunto, vide: BELVISO, Francesco. La nomina da parte dello Stato degli amministratori delle società privatizzate (art. 2, comma $1^{\circ}$, lett. d legge n. 474/1994). In: MARASÀ, Giogio (Org.). Profili giuridici delle privatizzazioni. Torino: G. Giappichelli Editore, 1997. p. 103-110, especialmente p. 104-105; CIRENEI, Maria Teresa. Le società di diritto 'speciale' tra diritto comunitario delle società e diritto comunitario della concorrenza: società a partecipazione pubblica, privatizzazioni e 'poteri speciali'. Diritto del Commercio Internazionale, Milano, n. XI, p. 771-829, 1996. p. 820; COSTI, Renzo. Privatizzazione e diritto delle società per azioni. Giurisprudenza Commerciale, Milano, n. XXII, parte I, fasc. 1, p. 77-100, 1995. p. 86; e SANTONASTASO, Felice. Le società di interesse nazionale. Milano: Dott. A. Giuffrè Editore, 2002. p. 77.

${ }^{70}$ Cumpre notar que a referência aos "objetivos nacionais de política econômica e industrial" foi introduzida por ocasião da conversão do Decreto-Lei n. 332 na Lei n. 474.

${ }^{71}$ Em 5 de outubro de 1995, Decreto do Presidente do Conselho de Ministros determinou a realização de Assembléia Geral da Eni s.p.a. para deliberar acerca da respectiva reforma estatutária.

${ }^{72}$ Item transcrito, juntamente com outras partes do estatuto da Eni s.p.a., em MARCHETTI, Piergaetano. Nuovi sviluppi delle privatizzazioni. Rivista delle Società, Milano, n. 40, fasc. 5-6, p. 1274-1285, sett./dic.1995, p. 1280-1281.
} 
da Fazenda era titular dos seguintes poderes: (i) aprovação de aquisição de participação correspondente a 3\% do capital social votante; (ii) aprovação de celebração de acordos ou pactos para-sociais que envolvessem ações com direito a voto representativas de $3 \%$ do capital social votante; (iii) veto nas deliberações que tivessem por objeto a dissolução, cisão ou fusão da companhia, a transferência de estabelecimento empresarial; a mudança da sede social para o exterior; a alteração do objeto social e a modificação da cláusula estatutária relativa aos poteri speciali; e (iv) eleição de um administrador e um Conselheiro Fiscal. Note-se que não havia previsão de prazo para manutenção desses poderes no Estatuto Social da Eni s.p.a.

Na Stet s.p.a. e na Telecom Italia s.p.a., os poteri speciali foram adotados em 1997. ${ }^{73}$ À semelhança do que se observou na Eni s.p.a, na Telecom Italia s.p.a. foram introduzidos todos os poteri speciali constantes do Decreto-Lei n. 332 e descritos acima. Porém, nesse caso, o direito de aprovar a celebração de acordos ou pactos para-sociais recaía sobre aqueles que tivessem por objeto ações representativas de $5 \%$ do capital social votante. Além disso, nos termos do estatuto social da Telecom Italia s.p.a., as prerrogativas estatais deveriam permanecer em vigor enquanto o processo de liberalização do setor de telecomunicações não tivesse alcançado suficiente estágio de desenvolvimento e o papel da autoridade de regulação setorial não estivesse consolidado, observado, no entanto, um período mínimo de três anos. ${ }^{74}$

O exercício desses poteri speciali pelo Estado foi objeto de intenso debate na Itália por ocasião da oferta pública feita pela Olivetti s.p.a. para aquisição da totalidade das ações ordinárias de emissão da Telecom Italia. ${ }^{75}$ No mesmo período, emergiam os questionamentos acerca da compatibilidade dos poteri speciali com os princípios do Direito comunitário europeu, notadamente a livre circulação de capitais e a livre iniciativa. ${ }^{76}$

Assim, para disciplinar o exercício dos poteri speciali e na tentativa de compatibilizar tal exercício com os princípios de direito comunitário, o presidente do Conselho de Ministros italiano editou, em 04 de maio de 1999 e em 11 de fevereiro de 2000, decretos intitulados “Direttiva per l'esercizio dei poteri speciali del ministro del

${ }^{73}$ Cf. Decreto do Presidente do Conselho de Ministros e Decreto do Ministro da Fazenda datados de 21 de março de 1997.

${ }^{74}$ Conforme art. $5^{\circ}$ do estatuto social da Telecom Italia s.p.a., transcrito às folhas 67 e 68 do Documento de Oferta Pública de Aquisição e Permuta de Ações Ordinárias da Telecom Italia s.p.a., subscrito pela Olivetti s.p.a. e Tecnost s.p.a. em 22 de abril de 1999 (disponível em: <http://www.storiaolivett.telecomitalia.it>. Acesso em: 20 jul. 2005).

${ }^{75}$ Sobre esses debates, confira-se DI PORTO, Fabiana. op. cit., p. 762.

${ }^{76}$ Nesse período, foi instaurado processo perante a Corte de Justiça da União Européia para apreciar a compatibilidade dos poteri speciali com o Tratado de Instituição da Comunidade Européia, especificamente com seus arts. 52, 59 e 73B, então vigentes. O processo, autuado sob n. C-58/99, foi encerrado em maio de 2000 com sentença que condenou a República Italiana pelo descumprimento de suas obrigações no âmbito da União Européia (disponível em: <http://www.europa.eu.int>. Acesso em: 30 jul. 2005). 
Tesoro, del bilancio e della programmazione economica (...)" e "Definizione dei critteri di esercizio dei poteri speciali (...)", respectivamente.

Segundo o disposto nesses decretos - cuja redação é bastante semelhante ${ }^{77}$ - os poteri speciali deviam ser exercidos nos casos e nos limites, inclusive temporais, previstos no estatuto social, observados os princípios de não-discriminação e de vinculação aos motivos de interesse geral que justificaram sua previsão estatutária, motivos esses relativos à ordem pública, segurança, saúde e defesa nacionais.

Especificamente quanto ao direito de aprovar a aquisição de participação societária relevante na companhia privatizada - atribuído ao Estado pela alínea "a" do art. 2, comma 1, do Decreto-Lei n. 332 - esses Decretos previram critérios objetivos para seu exercício, listando as hipóteses em que o ministro da Fazenda poderia deixar de conceder a aprovação. ${ }^{78}$

Após a edição desses Decretos, ou de pelo menos um deles, conforme o caso, outras companhias italianas passaram a contar com os poteri speciali. Trata-se das sociedades do grupo ENEL (ENEL s.p.a., ENEL Produzione s.p.a., ENEL Distribuizone s.p.a. e Terna s.p.a), grupo esse que desenvolve atividades no mercado de energia elétrica, e Finmeccanica s.p.a., companhia italiana que atua no setor de defesa e tecnologia.

No caso das sociedades do grupo ENEL, a previsão dos poteri speciali datou de setembro de 1999 e sua manutenção nos respectivos estatutos sociais deveria ser revista após 5 anos $^{79}$. Essa revisão levaria em conta a permanência das razões que haviam justificado a previsão inicial dos poteri e o estágio de desenvolvimento do processo de liberalização das fontes de energia na Europa.

À semelhança do que ocorreu na Eni s.p.a. e na Telecom Italia s.p.a, foram atribuídos ao Estado, no âmbito das sociedades do grupo ENEL, todos os poteri speciali relacionados no Decreto-Lei n. 332, a saber: ${ }^{80}(i)$ aprovação de aquisição de participação igual ou superior a 3\% do capital social votante ${ }^{81}$ (ii) aprovação de celebração de acordos ou pactos para-sociais que envolvessem ações com direito a voto representativas de 5\%

\footnotetext{
77 As principais diferenças entre eles decorrem da referência, no Decreto datado de 11 de fevereiro de 2000, ao art. 66, commi 3 a 5, da Lei n. 488, de 23 de dezembro de 1999.

${ }^{78}$ Dentre elas, encontravam-se as aquisições que $(\boldsymbol{i})$ não estivessem revestidas de suficiente transparência; (ii) pudessem comprometer processos de liberalização, não fossem coerentes com o processo de privatização ou prejudicassem o interesse público; (iii) pudessem comprometer os poteri speciali; ou (iv) fossem aptas a causar sérios prejuízos para o fornecimento de bens essenciais à coletividade, a continuidade da prestação de serviço público essencial e o desenvolvimento de setores tecnologicamente avançados.

${ }^{79}$ Nos termos do art. $2^{\circ}$ do Decreto do Presidente do Conselho de Ministros datado de 17 de setembro de 1999 (disponível em: <http://www.norminrete.it>. Acesso em: 31 maio 2005).

${ }^{80}$ Cf. Decreto do Ministro da Fazenda datado de 08 de outubro de 1999 (disponível em: < http://www.norminrete. it>. Acesso em: 31 maio 2005).

81 Percentual fixado em Decreto do Ministro da Fazenda, diverso do anteriormente citado, porém também datado de 17 de setembro de 1999 (disponível em: <http://www.norminrete.it>. Acesso em: 31 maio 2005).
} 
do capital social votante; (iii) veto nas deliberações que tivessem por objeto: a dissolução, cisão ou fusão da companhia, a transferência de estabelecimento empresarial, a mudança da sede social para o exterior, a alteração do objeto social e a modificação da cláusula estatutária relativa aos poteri speciali; e (iv) eleição de um administrador e um membro do Conselho Fiscal.

Na Finmeccanica s.p.a, Decreto do presidente do Conselho de Ministros, datado de 28 de setembro de 1999, determinou que, previamente à execução de qualquer ato relativo à privatização da companhia, deveria ser introduzida, no estatuto social, a cláusula relativa aos poteri speciali. ${ }^{82}$ No mesmo ano, passaram a constar do referido estatuto social todos os poteri speciali previstos no art. $2^{\circ}$ do Decreto-Lei n. 332.

Posteriormente à adoção dos poteri speciali por essas companhias - e em virtude dos questionamentos que se seguiram a essa adoção - o comma 1 do art. $2^{\circ}$ do Decreto-Lei n. 332 sofreu importante alteração, promovida pela Lei n. 350, de 24 de dezembro de $2003 .{ }^{83}$

Segundo a nova redação do dispositivo, ao Estado permaneciam reservadas as seguintes prerrogativas: (i) oposição à aquisição de participação relevante, correspondente a pelo menos a $5 \%$ do capital social votante; (ii) oposição à celebração de acordos ou pactos para-sociais que envolvessem ações com direito a voto representativas de, no mínimo, a 5\% do capital votante; e (iii) veto nas deliberações que tivessem por objeto a dissolução, cisão ou fusão da companhia, a transferência de estabelecimento empresarial, a mudança da sede social para o exterior, a alteração do objeto social, e a modificação da cláusula estatutária relativa aos poteri speciali.

No entanto, em inovação ao dispositivo anterior, previu-se que o exercício das prerrogativas referidas em (i) e (ii) deveria ser devidamente justificado, com demonstração de que a aquisição da participação relevante ou a celebração do acordo para-social geraria concreto prejuízo aos interesses vitais do Estado. Além disso, foi assegurado aos sócios contrários ao exercício de todas as prerrogativas acima indicadas, o direito de impugnar a decisão perante o Tribunal Administrativo Regional do Lazio.

Contudo, quanto ao direito de nomear administradores e membros do Conselho Fiscal da companhia privatizada - originalmente previsto no Decreto-Lei n. 332 - houve restrição das prerrogativas estatais, que ficaram limitadas à eleição de um administrador desprovido de direito de voto.

\footnotetext{
${ }^{82}$ Nos termos do Decreto do Presidente do Conselho de Ministros datado de 28 de setembro de 1999 (disponível em: $<$ http://www.norminrete.it $>$. Acesso em: 31 maio 2005). Segundo esse Decreto, a cláusula deveria ser mantida no estatuto social indefinidamente, até que novo Decreto do Presidente do Conselho de Ministros autorizasse sua supressão.

83 Referência é feita ao seu art. $4^{\circ}$, comma 227.
} 
De acordo com o art. $4^{\circ}$, comma 230 da Lei n. 350, caberia ao presidente do Conselho de Ministros individualizar, em decreto, os critérios de exercício dos poteri speciali, exercício esse restrito aos casos em que se observasse prejuízo aos interesses vitais do Estado.

Em cumprimento a esse dispositivo, foi editado, em 10 de junho de 2004, novo decreto do presidente do Conselho de Ministros. Tal como ocorrera nos decretos anteriores, esse normativo condicionou o exercício dos poteri speciali à existência de relevantes e imprescindíveis motivos de interesse geral, referentes à ordem, segurança e saúde públicas e à defesa, e à observância dos princípios de direito interno e comunitário, especialmente o princípio da não discriminação. Adicionalmente, relacionou, em seu art. $1^{\circ}$, comma 2, as circunstâncias que justificariam o exercício dos poderes de: oposição à aquisição de participação relevante, oposição à celebração de acordos para-sociais e veto. $^{84}$

Por fim, cumpre destacar que o art. $4^{\circ}$, comma 231 da Lei n. 350, reproduzido pelo art. 3, comma 1, do decreto do presidente do Conselho de Ministros, determinou a adaptação dos estatutos sociais que já contavam com os poteri speciali.

Realmente, essa adaptação pode ser observada nos estatutos sociais de companhias antes mencionadas, a saber: Eni s.p.a., ${ }^{85}$ ENEL s.p.a. ${ }^{86}$ e Finmeccanica s.p.a. ${ }^{87} \mathrm{Na}$ Telecom Italia s.p.a., ao que parece, não houve adequação estatutária, ${ }^{88}$ e os poteri speciali foram reduzidos a dois: (i) poder de aprovar previamente a aquisição de participação societária correspondente a 3\% do capital votante; e (ii) veto nas deliberações que recaiam sobre as matérias listadas no art. 2, comma 1, alínea "c" do Decreto-Lei n. 332 .

\footnotetext{
${ }^{84}$ Em linhas gerais, tais circunstâncias consistiam em: ameaça à continuidade da prestação de serviços públicos essenciais ou à distribuição de bens essenciais à coletividade; perigo para a defesa nacional, segurança militar, ordem pública ou segurança pública; ou, ainda, emergências sanitárias.

${ }^{85}$ Cf. item 6.2 do estatuto social da Eni s.p.a., aprovado pela Assembléia Geral em 13 de abril de 2005 (disponível em: <http://www.eni.it>. Acesso em: 27 jul. 2005).

${ }^{86}$ Cf. item 6.2 do estatuto social da Enel s.p.a., aprovado pela Assembléia Geral Extraordinária de 21 de maio de 2004 (disponível em: <http://www.enel.it>. Acesso em: 27 jul. 2005). Note-se que a modificação do estatuto social da Enel s.p.a. nesses termos, foi objeto de Decreto do Ministro da Economia datado de 17 de setembro de 2004 (disponível em: <http://www.normeinrete.it $>$. Acesso em: 17 jul. 2005).

${ }^{87}$ Cf. item 5.1 ter do estatuto social da Finmeccanica s.p.a, aprovado pela Assembléia Geral Extraordinária de 18 de julho de 2005 (disponível em: <http://www.finmeccanica.it>. Acesso em: 27 jul. 2005).

Note-se, por oportuno, que, nada obstante os poteri speciali, o Estado italiano ainda detém relevante participação no capital da Finmeccanica s.p.a.., participação essa correspondente, segundo informação constante dos arquivos da Commissione Nazionale per le Società e la Borsa - Consob, a cerca de 32,5 \% do capital votante (disponível em: <http://www.consob.it>. Acesso em: 27 jul. 2005).

${ }^{88}$ Cf. art. 22 do estatuto social da Telecom Italia s.p.a, aprovado pela Assembléia Geral em 7 de abril de 2005 (disponível em: $<$ http://www.telecomitalia.it $>$. Acesso em: 28 jul. 2005).
} 
O Estado italiano pouco se valeu dos poteri speciali: apenas quatro companhias contam com essa previsão estatutária.

\subsection{União Européia}

O primeiro pronunciamento oficial de um órgão da União Européia a respeito dos mecanismos de intervenção estatal, adotados pelos Estados-membros no âmbito de programas de privatização, foi o Comunicado da Comissão da Comunidade Européia referente a "determinados aspectos jurídicos dos investimentos intra-comunitários", datado de 19 de julho de $1997 .{ }^{89}$

Segundo esse Comunicado, embora os Estados-membros tenham plena competência para incluir a privatização dentre suas políticas públicas,$^{90}$ as medidas executórias para transferência do controle das companhias estatais ao setor privado não podem gerar obstáculos para o mercado comum, especialmente para os investimentos intra-comunitários. De fato, para a Comissão, tais investimentos, realizados tanto na forma de aquisição de controle de companhias como de compra e venda de ações negociadas em bolsa, são protegidos pelos princípios da livre circulação de capitais e da liberdade de estabelecimento.

Esses princípios, previstos respectivamente nos arts. 56 e 43 do Tratado de Instituição da Comunidade Européia, integram as chamadas "liberdades fundamentais" do Tratado e, por essa razão, não poderiam ser limitados pelos Estados-membros. No entanto, para a Comissão, algumas circunstâncias justificam uma limitação aos princípios, em caráter excepcional.

Para as chamadas "restrições discriminatórias" - i.e. dirigidas apenas a outros membros da União Européia - tais circunstâncias estão presentes se a restrição em análise: (i) for aplicável a atividades em que há exercício de autoridade pública pelo Estado-membro que a impôs; ou (ii) estiver relacionada a políticas públicas, segurança ou saúde pública; e (iii) constituir uma medida adequada e necessária para assegurar a proteção dos interesses públicos, de forma que não haja outro mecanismo capaz de atingir

\footnotetext{
${ }^{89}$ Inteiro teor disponível em: <http://www.europa.eu.int $>$. Acesso em: 08 mar. 2005. A respeito do Comunicado, vide LLOYD, Tracey; ROBERT, Gavin. Golden shares and European law. European counsel, London, n. 2, fasc. 10, p. 37-40, 1998.

${ }^{90}$ Esse entendimento da Comissão decorre da interpretação do art. 295 do Tratado de Instituição da Comunidade Européia, que determina a não interferência no regime de propriedade adotado pelos Estados-membros. Para Wouter Devroe, porém, a Comunidade Européia não observou a neutralidade prevista nesse artigo e, mediante a edição de diversas normas, incentivou a opção pelas políticas de privatização (DEVROE, Wouter. Privatizations and community law: neutrality versus policy. Common Market Law Review, Leiden, n. 34, p. 267-306, 1997. p. 268). No mesmo sentido, confira-se: VERHOEVEN, Amaryllis. Privatisation and the EC law: is the European commission "neutral" with respect to public versus private ownership of companies? International and Comparative Law Quarterly, Oxford, n. 4, p. 861-887, 1996.
} 
os mesmos resultados com menor limitação aos princípios da liberdade de circulação de capitais e liberdade de estabelecimento. ${ }^{91}$ Além disso, para a Comissão, as restrições não devem ser interpretadas extensivamente e não podem ser justificadas somente por razões econômicas.

Já as chamadas "restrições não-discriminatórias" - entendidas como tais as endereçadas indistintamente aos nacionais do Estado-membro que a impôs e aos demais Estados-membros - podem ser admitidas se $(\boldsymbol{i})$ realmente forem aplicadas de forma não discriminatória, e não apenas previstas como tais; (ii) fundarem-se em razões de interesse geral; (iii) representarem medida adequada ao alcance do objetivo por elas visado; e (iv) não excederem o que seria necessário para atingir esse objetivo.

Após a edição desse Comunicado, que visou a indicar aos Estados-membros o entendimento da Comissão sobre a interpretação dos arts. 56 e 43 do Tratado de Instituição da Comunidade Européia, diversos processos foram instaurados perante a Corte de Justiça da Comunidade Européia para averiguar a compatibilidade das restrições fixadas pelos Estados-membros em sua legislação interna com o Direito comunitário europeu. ${ }^{92}$

O primeiro desses processos, de número C-58/99, teve como partes a Comissão da Comunidade Européia e a República da Itália. Nele, foram objeto de análise os poteri speciali detidos pelo Estado italiano no capital da ENI s.p.a. e Telecom Italia s.p.a., nos termos dos arts. 1 e 2 do Decreto-Lei n. 332, de 31 de maio de 1994, modificado pela Lei n. 474, de 30 de julho de 1994.

A Comissão da Comunidade Européia entendia que os poteri speciali assim previstos não satisfaziam as quatro condições aplicáveis às restrições não-discriminatórias acima descritas. Ao final desse processo, em 23 de maio de 2000, a Corte de Justiça acolheu o parecer do advogado-geral M. Jean Mischo e condenou a República italiana pelo descumprimento de suas obrigações no âmbito da União Européia. ${ }^{93}$

Ao processo instaurado contra a República italiana seguiram-se outros, abertos contra Portugal (C-367/98), França (C-483/99) e Bélgica (C-503/99). ${ }^{94}$

\footnotetext{
${ }_{91}$ Trata-se, nas palavras do Comunicado, do "teste da proporcionalidade" concebido e aplicado pela Corte de Justiça da União Européia às restrições aos princípios fundamentais de Direito comunitário.

${ }_{92}$ Tais processos foram instaurados a partir das informações fornecidas pelos Estados-membros à Comissão Européia, em resposta ao "questionário sobre investimento intra-comunitário" a eles endereçado em 1997. Sobre os quesitos desse questionário, confira-se: European Commission. Special rights in privatised companies in the enlarged union: a decade full of developments. Commission Staff working document. 22 July 2005. Disponível em: <http://ec.europa.eu/internal_market/capital/docs/privcompanies_en.pdf>. Acesso em: 17 abr. 2006, p. 13, 31-32.

${ }^{93}$ Inteiro teor do parecer e da sentença disponíveis em <http://www.europa.eu.int>. Acesso em: 30 jul. 2005.

${ }^{94}$ Inteiro teor das sentenças proferidas pela Corte de Justiça nesses processos e do parecer do Advogado-Geral disponíveis em: <http://www.europa.eu.int >. Acesso em: 30 jul. 2005. A descrição dos casos contida nesse item baseia-se nas informações constantes desses documentos.
} 
O processo instaurado contra Portugal dizia respeito aos poderes reservados ao Estado no âmbito do programa de privatizações implementado pela Lei n. 11/90 e pelos Decretos-Lei n. 380/93 e n. 65/94. O processo instaurado contra a França recaía especificamente sobre a action spécifique detida pelo Estado francês no capital social da Société Nationale Elf-Aquitaine, cujos poderes estavam previstos no decreto n. 93.1298. Por fim, o processo aberto contra o Reino da Bélgica tinha por objeto as prerrogativas conferidas ao Estado no âmbito de duas companhias: Société Nationale de Transport par Canalisations e Distrigaz.

Diante da semelhança existente entre esses três casos, o advogado-geral Ruiz-Jarabo Colomer proferiu parecer conjunto, em 03 de julho de 2001. Nesse parecer, o advogado-geral qualificou como discriminatória e, portanto, contrária aos princípios da livre circulação de capitais e da liberdade de estabelecimento a proibição, prevista na legislação portuguesa, de aquisição, por parte de investidores oriundos de Estados-membros diversos de Portugal, de mais de determinado número de ações de emissão de companhias portuguesas. As restrições previstas nas demais normas eram, para o advogado-geral, nãodiscriminatórias e compatíveis com o Direito comunitário europeu, em virtude da regra de neutralidade da União Européia quanto ao regime da propriedade privada dos Estadosmembros, inscrita no art. 295 do Tratado de Instituição da Comunidade Européia. Nesse sentido, o parecer opina pela condenação da República portuguesa por descumprimento de suas obrigações comunitárias e pela improcedência das pretensões apresentadas pela Comissão relativas às restrições não-discriminatórias existentes na legislação de Portugal, França e Bélgica. ${ }^{95}$

Apesar de tais razões, a Corte de Justiça da Comunidade Européia não acolheu integralmente o aludido parecer. Em sentenças proferidas em 04 de junho de 2002, a Corte condenou as Repúblicas de Portugal e da França por violação do Tratado de Instituição da Comunidade Européia. O caso C-503/99, instaurado contra a Bélgica, foi o único em que o pedido da Comissão foi considerado improcedente. Segundo a Corte de Justiça, os poderes concedidos ao Estado no âmbito da Société Nationale de Transport par Canalisations e Distrigaz eram necessários e adequados à proteção do interesse público, representado pela preservação das reservas e do fornecimento de gás natural em eventual crise. Para a Corte, as seguintes circunstâncias demonstravam tal necessidade e adequação e justificavam, portanto, a restrição aos princípios da livre circulação de capitais e liberdade de estabelecimento, nos termos do Comunicado de 19 de julho de 1997: (i) os poderes foram concebidos sob a forma de oposição posterior e não como autorização prévia, de

\footnotetext{
${ }_{95}$ Para críticas ao parecer, vide KRONENBERGER, Vincent. The rise of the "golden" age of free movement of capital: a comment on the golden shares judgments of the Court of Justice of the European Communities. European Business Organization Law Review, Hague, n. 4, p. 115-136, 2003. p. 126-127.
} 
modo que eram respeitadas as competências e a autonomia dos órgãos das companhias; (ii) havia prazo para que o Estado exercesse seu direito de oposição; (iii) os poderes diziam respeito somente às deliberações relativas aos ativos estratégicos da companhia e só poderiam ser exercidos se houvesse ameaça aos objetivos de política energética do país; (iv) o eventual exercício dos poderes estatais poderia ser objeto de revisão judicial; e, por fim, (v) a Comissão da Comunidade Européia não demonstrou que medidas menos restritivas poderiam ter sido empregadas pela Bélgica para atingir os mesmos objetivos.

Esses três julgados, com destaque para aquele proferido no processo C503/99 instaurado contra a Bélgica, constituem importantes precedentes na jurisprudência da Corte de Justiça da Comunidade Européia. A eles, seguiram-se os processos instaurados contra a Espanha (C-463/00) e contra o Reino Unido (C-98/01). ${ }^{96}$

O processo C-463/00 pretendia analisar a compatibilidade, com o Direito comunitário europeu, do assim chamado "sistema de prévia aprovação administrativa" instituído pela Lei n. 05/1995 no âmbito do programa de privatizações espanhol. ${ }^{97}$ Essa Lei, aplicável às companhias com participação estatal superior a $25 \%$ do capital social cujas atividades estivessem vinculadas à consecução do interesse público, sujeitava a realização de certos atos da companhia à autorização administrativa. Também integrava o objeto do processo C-463/00 a adoção desse sistema pelas companhias espanholas Repsol SA, Telefónica de España SA, Telefónica Servicios Móviles SA, Corporación Bancaria de España SA, Tabacalera SA e Endesa SA. Segundo a Comissão da Comunidade Européia, o Estado espanhol, na concepção e aplicação do referido sistema, deixou de cumprir as condições previstas no Comunicado de 19 de julho de 1997.

O processo C-98/01 recaía sobre a special redeemable share detida pelo Reino Unido no capital social da British Airport Authority plc. Para a Comissão, embora a referida special share fosse considerada uma restrição não-discriminatória aos princípios da livre circulação de capitais e liberdade de estabelecimento, sua adoção não encontrava justificativas de interesse geral e, nesse sentido, também não atendia aos requisitos do Comunicado de 19 de julho de 1997.

A respeito desses dois casos, o advogado-geral Ruiz-Jarabo Colomer proferiu, em 06 de fevereiro de 2003, parecer conjunto. O advogado-geral entendeu que as potenciais restrições ao princípio da liberdade de circulação de capitais decorrentes

\footnotetext{
96 Inteiro teor das sentenças proferidas pela Corte de Justiça nesses processos e do parecer do Advogado-Geral disponíveis em: <http://www.europa.eu.int>. Acesso em: 30 jul. 2005. A descrição dos casos contida nesse item baseia-se nas informações constantes desses documentos.

${ }^{97}$ A respeito, vide MORENILLA, José María Souvirón. La privatización del sector publico empresarial del Estado en España (1996-2002). Aspectos jurídicos. In: ORTIZ, Gaspar Ariño (Org.). Privatizaciones y liberalizaciones en España: balance y resultados (1996-2003). Granada: Comares Editorial, 2004. t. I. p. 159, especialmente p. 14-15.
} 
do sistema de prévia autorização administrativa espanhol eram plenamente justificáveis e adequadas aos fins visados pelo Estado. Estavam presentes no caso espanhol, em sua opinião, todos os requisitos identificados pela Corte de Justiça no caso belga. Por essa razão, sugeriu que a pretensão aduzida pela Comissão da Comunidade Européia fosse julgada improcedente.

O mesmo não se observou no caso britânico. Segundo o advogado-geral, não foram previstos critérios objetivos para exercício dos direitos inerentes à special redeemable share emitida pela British Airport Authority plc, nem a submissão desse exercício à revisão judicial. Nesse sentido, o advogado-geral opinou pela condenação do Reino Unido no processo C-98/01.

A Corte de Justiça da Comunidade Européia efetivamente condenou o Reino Unido em sentença proferida em 13 de maio de 2003, porém por razões distintas das aduzidas pelo advogado-geral. Na mesma data, a Corte proferiu sentença igualmente condenatória em relação à Espanha, contrariando a orientação do advogado-geral.

Nocasoespanhol,aCorte inicialmenteconsiderouqueinexistiamjustificativas de interesse geral para a manutenção do sistema de prévia aprovação administrativa nas sociedades Tabacalera SA e Corporación Bancaria de España SA. Quanto às demais companhias, embora tenha reconhecido a presença de interesses públicos estratégicos, a Corte entendeu, com base nos julgamentos precedentes, que o procedimento previsto para exercício dos poderes estatais concedia às autoridades administrativas excessiva margem de discricionariedade, pois prescindia de critérios claros e amplamente divulgados.

No caso britânico, a Corte de Justiça concluiu que a atribuição ao Estado das prerrogativas representadas pela special share importava limitação ao princípio da liberdade de circulação de capitais e ao princípio da liberdade de estabelecimento. Em virtude da decisão da Corte de Justiça, a special share emitida pela British Airport Authority foi cancelada em julho de 2004.98

$\mathrm{O}$ teor desses dois julgados, e especialmente sua divergência com o parecer do advogado-geral, revelam que a polêmica acerca da compatibilidade das golden shares com o Direito comunitário europeu não está encerrada, sequer atenuada.

Evidência adicional dessa circunstância são os processos recentemente instaurados perante a Corte de Justiça: (i) caso C-282/04, instaurado em 30 de junho de 2004 contra o Reino dos Países Baixos; (ii) caso C-283/04, instaurado em $1^{\circ}$ de julho de

\footnotetext{
${ }_{98}$ Conforme item 22 do Relatório Anual 2004/2005 da British Airport Authority plc disponível em: < http:// www.baa.co.uk>. Acesso em: 15 set. 2005.
} 
2004 também contra o Reino dos Países Baixos; e (iii) caso C-112/05, iniciado em 04 de março de 2005 contra a Alemanha. ${ }^{99}$

No primeiro, discutiu-se a golden share detida pelo Estado na Koninklijke KPN NV, companhia com atuação na área de telecomunicações; enquanto no segundo analisou-se golden share de emissão da TNT Postgroep NV, prestadora de serviços de distribuição e logística. Em ambos, as golden shares conferiam ao Estado poder de aprovar previamente determinadas matérias, como por exemplo: emissão de ações, fusão, dissolução, alteração do objeto social. ${ }^{100}$ Em despacho datado de 23 de novembro de 2005, o presidente da Corte de Justiça da União Européia decidiu que ambos os processos passariam a tramitar em conjunto. Em 06 de abril de 2006, o advogado-geral M. Poiares Maduro proferiu parecer sobre os casos. Em que pese a argumentação do Reino dos Países Baixos, no sentido de que o Estado seria titular das golden shares na qualidade de agente econômico não como autoridade pública, o advogado-geral entendeu que referidas golden shares constituem restrição à livre circulação de capitais e, por essa razão, opinou pela condenação do Reino dos Países Baixos. Em 28 de setembro de 2006, a Corte de Justiça acolheu o parecer do advogado-geral e proferiu decisão condenatória. ${ }^{101}$

O caso C-112/05 visa a averiguar a compatibilidade, com o Direito comunitário europeu, de determinados dispositivos da legislação alemã que disciplinou a privatização da Volkswagen AG. ${ }^{102}$

\footnotetext{
99 Além dos processos citados neste parágrafo cumpre mencionar o processo C-174/04, instaurado contra a República Italiana em abril de 2004 e já julgado pela Corte de Justiça da União Européia. Embora não tenha por objeto os poteri speciali italianos, esse caso relaciona-se à problemática das golden shares. A pedido da Comissão da Comunidade Européia, o processo visava a averiguar a compatibilidade de dispositivo da legislação italiana (art. $1^{\circ}$ do Decreto-Lei n. 192, de 25 de maio de 2001, convertido na Lei n. 3.011, de 20 de julho de 2001) com o princípio da livre circulação de capitais. Tal dispositivo previa a suspensão dos direitos de voto das participações superiores a $2 \%$ do capital social das companhias italianas que atuam no setor de gás e eletricidade. Em seu parecer, a Advogada-Geral Juliane Kokott opinou pela condenação da República Italiana. A Corte, invocando como precedentes os casos sobre golden shares, acolheu tal parecer e proferiu decisão desfavorável à Itália em 02 de junho de 2005 (informações disponíveis em: <http://www.europa.eu>. Acesso em: 02 mar. 2006).

${ }^{100}$ Interessante notar que, em acordo, o Reino dos Países Baixos comprometeu-se a não usar os poderes atribuídos pelas golden shares para proteger as companhias de aquisições hostis (cf. item 10 da sentença proferida pela Corte de Justiça da União Européia, disponível em: <http://www.europa.eu.int>. Acesso em: 30 dez. 2006).

${ }^{101}$ Inteiro teor do parecer do Advogado-Geral e da sentença disponíveis em: $<$ http://www.europa.eu.int $>$. Acesso em: 30 dez. 2006.

${ }^{102}$ São, especificamente, os parágrafos 2(1), 4(1) e 4(3), que: (i) limitam os direitos de voto de cada acionista a $20 \%$ do capital social da companhia; (ii) determinam que a República Alemã e o Estado da Baixa Saxônia podem indicar, individualmente, 2 membros do Conselho da companhia; e (iii) elevam o quorum de deliberação da Assembléia Geral da companhia para 80\% (cf. nota publicada na edição de 11.6.2005 do Official Journal of European Union, disponível em: <http://www.europa.eu.int>. Acesso em: 15 set. 2005). Esse processo foi julgado em 23 de outubro de 2007, desfavoravelmente à Alemanha.
} 
Além dos processos que já se encontram em andamento, há relevantes possibilidades de instauração de novos casos, ${ }^{103}$ devido à presença de golden shares em diversas companhias européias. Segundo estudo realizado pela Comissão da Comunidade Européia, com base em informações prestadas pelos próprios Estados-membros, 141 companhias européias apresentavam golden shares em julho de 2004. ${ }^{104}$

\subsection{Brasil}

No Brasil, a chamada "ação de classe especial” foi originalmente prevista pela Lei n. 8.031, de 12 de abril de 1990, que institui o Programa Nacional de Desestatizações - PND.

Nos termos do art. $1^{\circ}$ dessa lei, o programa tinha por objetivos: “( $\left.\boldsymbol{i}\right)$ reordenar a posição estratégica do Estado na economia, transferindo à iniciativa privada atividades indevidamente exploradas pelo setor público; (ii) contribuir para a redução da dívida pública, concorrendo para o saneamento das finanças do setor público; (iii) permitir a retomada de investimentos nas empresas e atividades que vierem a ser transferidas à iniciativa privada; (iv) contribuir para a modernização do parque industrial do país, ampliando sua competitividade e reforçando a capacidade empresarial nos diversos setores da economia; (v) permitir que a administração pública concentre seus esforços nas atividades em que a presença do Estado seja fundamental para a consecução das prioridades nacionais; (vi) contribuir para o fortalecimento do mercado de capitais, através do acréscimo de oferta de valores mobiliários e da democratização da propriedade do capital das empresas que integrarem o programa".

\footnotetext{
${ }^{103}$ Segundo Christine O'Grady Putek, embora nenhum processo tenha sido instaurado perante a Corte de Justiça até o momento, a Comissão já adotou medidas para tanto preparatórias contra Luxemburgo, Dinamarca e novamente Itália (Limited but not lost: a comment on the ECJ's golden share decisions. Fordham law review, New York, n. 72, p. 2219-2285, 2004. p. 2278-2279).

${ }^{104}$ European Comission. Special rights in privatised companies in the enlarged union: a decade full of developments. Comission Staff working document. 22 July 2005. Disponível em: $<$ http://ec.europa.eu/internal market/capital/docs/privcompanies_en.pdf $>$. Acesso em: 17 abr. 2006. p. 19, 33-38. Pedro de Albuquerque e Maria de Lurdes Pereira afirmam que esse número não é exato, pois alguns Estados-membros, como Bélgica, Grécia e Portugal, não prestaram as informações solicitadas e há companhias britânicas emissoras de golden shares que não foram indicadas no estudo da Comissão (ALBUQUERQUE, Pedro de; PEREIRA. Maria de Lurdes. As "golden shares" do estado português em empresas privatizadas: limites à sua admissibilidade e exercício. Coimbra: Coimbra Editora, 2006. p. 40).
} 
Para alcançar esses objetivos, a referida lei autorizou a alienação a particulares, dos direitos que asseguravam à União Federal o exercício do controle acionário $^{105}$ em sociedades empresariais. ${ }^{106}$

Por ocasião dessa alienação e mediante sugestão da Comissão Diretora do PND, poderia ser reservada à União Federal a titularidade de uma ação de classe especial. $^{107}$

Note-se que a Lei n. 8.031/90 não disciplinou, em detalhes, as hipóteses que justificariam a emissão da ação de classe especial, nem mesmo os direitos a ela inerentes. ${ }^{108}$ $\mathrm{O}$ art. $8^{\circ}$ da lei limitou-se a prever: "sempre que houver razões que o justifiquem, a União deterá, direta ou indiretamente, ações de classe especial do capital social de empresas privatizadas, que lhe confiram poder de veto em determinadas matérias, as quais deverão ser caracterizadas nos estatutos sociais das empresas (...)".

Esse dispositivo foi reproduzido nas normas que regulamentaram a lei, ${ }^{109}$ normas essas consolidadas no Decreto n. 1.204, de 29 de julho de 1994, cujo art. 43 dispunha: "havendo razões que o justifique, a União deterá ações de classe especial do capital social de sociedade privatizada, que conferirão poder de veto de determinadas matérias previstas no estatuto". ${ }^{110}$

\footnotetext{
${ }^{105}$ Note-se que o art. $2^{\circ}, \S 1^{\circ}$ da Lei n. 8.031 refletiu, em parte, o conceito de controle acionário contido no art. 116 da Lei n. 6.404, de 15 de dezembro de1976, ao dispor: "§ $1^{\circ}$ Considera-se privatização a alienação, pela União, de direitos que lhe assegurem, diretamente ou através de outras controladas, preponderância nas deliberações sociais e o poder de eleger a maioria dos administradores da sociedade".

${ }^{106}$ Segundo o art. $2^{\circ}$, incisos I e II, da Lei n. 8.031, eram objeto do programa todas as empresas "controladas, direta ou indiretamente pela União e instituídas por lei ou ato do Poder Executivo, e as sociedades criadas pelo setor privado que, por qualquer motivo, passaram ao controle, direto ou indireto, da União".

${ }^{107}$ Conforme art. $6^{\circ}$, inciso XIII da Lei n. 8.031: "Art. $6^{\circ}$ Compete à Comissão Diretora do Programa Nacional de Desestatização: (...) XIII - sugerir a criação de ações de classe especial e as matérias que elas disciplinarão, nas condições fixadas nos $\S \S 1^{\circ}$ e $2^{\circ}$ deste artigo. $\S 1^{\circ}$ (Vetado). $\S 2^{\circ} \mathrm{A}$ ação de classe especial somente poderá ser subscrita pela União." O parágrafo $1^{\circ}$, alvo de veto presidencial, tinha a seguinte redação: "A ação de classe especial, que não terá valor pecuniário, em número de apenas uma, concede ao seu detentor poder de veto sobre as seguintes matérias, entre outras: a) alterações estatutárias de qualquer natureza; b) fixação de preços; c) transferência do controle acionário". Vale transcrever as razões do veto: "revelam-se excessivos os poderes conferidos aos detentores da ação de classe especial, o que redundará, à toda evidência, na redução do valor do controle acionário da empresa a ser privatizada, quando, na realidade, tais poderes devem depender das especificidades de cada empresa, tal como preceituam, de modo satisfatório, o inciso XIII do próprio art. $6^{\circ} \mathrm{e}$ o inciso XV do art. 21 do projeto" (Mensagem de veto disponível em: <www.planalto.gov.br $>$ Acesso em: 17. dez. 2006).

${ }^{108}$ A ausência de disciplina desses poderes decorreu do veto presidencial acima mencionado.

${ }^{109}$ Trata-se dos seguintes decretos: Decreto n. 99.463, de 16 de agosto de 1990 - alterado pelos Decretos n. 215, de 18 de agosto de 1991, n. 700, de 16 de dezembro de 1992 e n. 712, de 24 de dezembro de 1992 - e Decreto n. 724, de 19 de janeiro de 1993 - alterado pelos Decretos n. 786, de 30 de março de 1993 e n. 798, de 16 de abril de 1993 (Cf. informações disponíveis em: <http://www.senado.gov.br>. Acesso em: 16 set. 2005). Ambos continham dispositivos sobre a ação de classe especial, de mesmo teor do artigo acima transcrito.

${ }^{110}$ Competia à Comissão Diretora, nos termos do parágrafo $2^{\circ}$ do mesmo art. 43 , fundamentar a necessidade da criação da ação de classe especial, especificar sua quantidade, as matérias passíveis de veto e estabelecer a forma de sua aquisição pela União Federal.
} 
Sob a égide da Lei n. 8.031/90, previu-se a emissão da ação de classe especial em três companhias privatizadas, ${ }^{111}$ a saber: Companhia Eletromecânica Celma, prestadora de serviços de reparo, revisão e manutenção de motores aeronáuticos; Empresa Brasileira de Aeronáutica S.A. - Embraer, que atua no setor aeroespacial e de defesa; e Companhia Vale do Rio Doce, cujas atividades se concentram no ramo de mineração.

A Companhia Eletromecânica Celma foi uma das primeiras companhias a ser incluída no Programa Nacional de Desestatizações, fato ocorrido em novembro de 1990 com a edição do Decreto n. 99.666. Em 15 de julho de 1991, foi publicado no Diário Oficial da União o edital para alienação das ações de emissão da companhia, de n. PND/A-02/91/CELMA. ${ }^{112}$ Segundo o item 7.1.3 desse edital, após a privatização, seria reservada à União Federal uma ação ordinária de classe $\mathrm{B}$, com direito de aprovar qualquer alteração dos seguintes artigos do estatuto social: $(\boldsymbol{i})$ art. $3^{\circ}$, inciso I, relativo ao objeto social; ${ }^{113}$ (ii) art. $6^{\circ}$, que estabelecia limite para participação de companhias aéreas no capital da Companhia Eletromecânica Celma; ${ }^{114}$ e (iii) art. 9º que tratava da composição do Conselho de Administração da sociedade e concedia à União Federal a prerrogativa de indicar um de seus membros. ${ }^{115}$ Ainda de acordo com o edital, a ação ordinária de classe B seria convertida em ação ordinária no prazo de 10 anos, contados da aprovação do estatuto social anexo ao edital de privatização, salvo manifestação prévia da União no sentido de prorrogar tal prazo por mais 10 anos. ${ }^{116}$

A Embraer foi incluída no Programa Nacional de Desestatizações em janeiro de 1992 por força do Decreto n. 423. Em 04 de abril de 1994, foi publicado o edital "para alienação de ações do capital da companhia", de n. PND-A-05/94/Embraer, ${ }^{117}$ cujo item

${ }^{111}$ Cf. CANTIDIANO, Luiz Leonardo. Reforma da lei das S.A. comentada. Rio de Janeiro: Renovar, 2002. p. 88.

${ }^{112}$ Edital obtido junto ao Centro de Documentação do Banco Nacional de Desenvolvimento Econômico e Social - BNDES.

${ }^{113}$ Confira-se o teor do artigo, tal como transcrito no edital: "Art. $3^{\circ}$. A Celma tem por objetivo: I. projetar, construir, reparar e revisar motores aeronáuticos, inclusive ferramentas, instrumentos, peças, acessórios e componentes; $(. .$.$) "$

${ }^{114}$ In verbis: “Art. $6^{\circ}$ As companhias aéreas, seus controladores, controladas, coligadas e seus administradores não poderão deter, em seu conjunto, mais de $30 \%$ de ações representativas do capital votante da companhia. $\S$ $1^{\circ}$ Cada companhia aérea, em conjunto com seus controladores, controladas, coligadas e seus administradores, não poderá deter mais de $10 \%$ de ações representativas do capital votante da companhia. $\S 2^{\circ}$ As disposições previstas no caput deste artigo têm validade de 5 anos contados a partir da data de entrada em vigor do presente estatuto".

115 “Art. $9^{\circ} \mathrm{O}$ Conselho de Administração será constituído por um mínimo de 6 e máximo de 10 membros, eleitos pela Assembléia Geral, sendo obrigatoriamente um indicado pela União e outro indicado pelos empregados da Celma”. Interessante notar que a indicação de membro do Conselho de Administração, embora prevista no estatuto social como uma prerrogativa da União Federal, não estava diretamente vinculada à detenção da ação de classe especial.

${ }^{116}$ Não há notícias sobre o uso dessa faculdade pela União Federal.

${ }^{117}$ Edital obtido junto ao Centro de Documentação do Banco Nacional de Desenvolvimento Econômico e Social - BNDES. 
2.2.1 se referia à ação de classe especial nos seguintes termos: "deverá ser criada 'golden share', ${ }^{118}$ a ser detida exclusivamente pela União, com veto nas seguintes matérias: (i) mudança do objeto social; (ii) alteração e/ou aplicação da logomarca da empresa; (iii) criação e alteração de programas militares que envolvam - ou não - a República Federativa do Brasil; (iv) capacitação de terceiros em tecnologia para programas militares; (v) interrupção do fornecimento de peças de manutenção e reposição de aeronaves militares; (vi) transferência do controle acionário; (vii) quaisquer modificações no Estatuto Social que alterem os arts. $9^{119}$ e 15 e seus parágrafos, ${ }^{120}$ ou quaisquer vantagens, preferências ou direitos atribuídos à 'golden share"'. Em dezembro de 1994, a União Federal alienou, em leilão, as ações de emissão da companhia de sua propriedade, reservando-se, porém, a titularidade de uma "ação ordinária de classe especial", com poder de veto em deliberações sobre matérias referidas acima, consideradas estratégicas para o Estado brasileiro. ${ }^{121}$

Sobre essa ação de classe especial, é interessante mencionar que, em 1999, o Governo brasileiro pretendeu vetar a alienação, pelos controladores da Empresa Brasileira de Aeronáutica S.A. a um grupo francês, de $20 \%$ das ações ordinárias de emissão da companhia. Discutiu-se, na ocasião, se a alienação poderia ser qualificada como transferência de controle acionário e, nesse sentido, se estaria sujeita ao veto da União Federal. ${ }^{122}$

A Companhia Vale do Rio Doce, por sua vez, foi incluída no Programa Nacional de Desestatizações pelo Decreto n. 1.510, de 06 de junho de 1995. Em 06 de março de 1997, foi publicado o edital para alienação das ações da companhia, de n. PND/

\footnotetext{
${ }^{118}$ O edital assim definiu a "golden share" em seu item 1.1, XVII: "é a ação de classe especial cuja propriedade é exclusiva da União Federal, a ser criada na alteração dos Estatutos Sociais a se realizar através de AGE anterior à data do leilão".

${ }^{119}$ Trata-se do artigo que indicava as prerrogativas da ação ordinária de classe especial.

${ }^{120}$ Esse artigo dispunha acerca da composição do Conselho de Administração da companhia e atribuía à União Federal o direito de indicar um de seus membros e respectivo suplente. À semelhança do que se observou no estatuto social da Companhia Eletromecânica Celma, esse direito não estava direta e expressamente vinculado à ação de classe especial.

${ }^{121}$ Em cumprimento ao disposto no edital, as modificações no estatuto social da Empresa Brasileira de Aeronáutica S.A. foram realizadas previamente ao leilão. Em 27 de junho de 1994, Assembléia Geral Extraordinária da companhia aprovou a alteração do respectivo estatuto social, que passaria a vigorar após a "efetiva desestatização da companhia, nos termos do edital de privatização (...), considerando-se como efetiva desestatização a eficácia do leilão, com sua respectiva liquidação". No entanto, no estatuto social aprovado, foi incluída, dentre as matérias suscetíveis de veto pela União Federal, a alteração da denominação social, que não constava do edital. Cf. ata arquivada na Junta Comercial do Estado de São Paulo sob n. 91.060/94-1, em sessão de 30 de junho de 1994.

${ }^{122}$ Sobre tal discussão, vide parecer de (SILVA, Luiz Alberto da. Transferência de ações ordinárias da Empresa Brasileira de Aeronáutica S.A. - Embraer - dos acionistas controladores da companhia a empresas francesas. Revista de Direito Bancário, do Mercado de Capitais e da Arbitragem, São Paulo, n. 8 p. 197-217, abr./jun. 2000). Para o autor, a alienação não representava transferência de controle acionário da companhia e, portanto, não se enquadrava no âmbito do poder de veto da ação de classe especial.
} 
A-01/97/CVRD. ${ }^{123}$ Segundo o item 3.2 desse edital, após a realização do leilão de venda das ações de emissão da Companhia Vale do Rio Doce, a União Federal permaneceria titular de participação direta e indireta na companhia, participação essa representada, no primeiro caso, por ação de classe especial emitida pela própria Companhia Vale do Rio Doce e, no segundo caso, por ação preferencial de classe "A" emitida pela sociedade adquirente das ações ofertadas em leilão. ${ }^{124}$

Nos termos do item 3.2.1 do edital, a ação de classe especial de emissão da Companhia Vale do Rio Doce garantia à União Federal veto nas deliberações da Assembléia Geral que tivessem por objeto: (i) a alteração da denominação social; (ii) mudança da sede social; (iii) mudança do objeto social, no que se refere à exploração mineral; (iv) liqüidação da companhia; (v) alienação ou encerramento das atividades de qualquer uma ou do conjunto das seguintes etapas dos sistemas integrados de minério de ferro da companhia, a saber: (a) depósitos minerais, jazidas, minas; (b) ferrovias; (c) portos e terminais marítimos; (vi) quaisquer modificações dos direitos atribuídos à ação de classe especial da companhia. Já a ação preferencial de classe "A" emitida pela sociedade adquirente das ações da Companhia Vale do Rio Doce atribuiria, de acordo com o item 3.2.2 do edital, "direito exclusivo de deliberar" sobre as seguintes matérias, submetidas à Assembléia Geral: (i) alteração no objeto social; (ii) modificações nas regras sobre limites de participação individual ou conjunta de acionistas em seu capital social; (iii) liqüidação, dissolução, transformação, cisão, fusão ou incorporação por outra sociedade; (iv) modificações nas regras de desconcentração aplicáveis a seus acionistas; (v) alienação, oneração ou transferência, sob qualquer forma, de ações ordinárias ou de quaisquer valores mobiliários permutáveis em ações ordinárias do capital da Companhia Vale do Rio Doce de propriedade da sociedade, exceto ações ordinárias adquiridas fora do âmbito do leilão e desde que mantido, nessa sociedade, no mínimo, o mesmo percentual dessas ações adquiridas no leilão; e (vi) qualquer modificação nos direitos atribuídos à ação preferencial de classe "A". Segundo o item 3.2, "b" do edital, tal ação preferencial de classe "A" vigoraria pelo prazo de 5 anos e seria atribuída à BNDES Participações S.A., que deveria exercer os direitos a ela inerentes no interesse da União Federal.

O processo de privatização da Companhia Vale do Rio Doce foi acompanhado por intensos debates, inclusive sobre a legalidade da atribuição de uma ação de classe especial ao Estado brasileiro.

\footnotetext{
${ }^{123}$ Edital obtido junto ao Centro de Documentação do Banco Nacional de Desenvolvimento Econômico e Social - BNDES.

${ }^{124}$ Segundo o item 2.2.5 do edital, poderiam participar do leilão quaisquer pessoas físicas ou jurídicas, brasileiras ou estrangeiras, desde que organizadas sob "a forma de sociedade de propósito específico", i.e., cujo objeto social consistisse na administração da participação acionária na Companhia Vale do Rio Doce (cf. item 1.1 do edital).
} 
Duas ações judiciais podem ser citadas para ilustrar o teor desses debates. Trata-se da ação popular com pedido de medida liminar ajuizada, em 22 de abril de 1997 , contra o Banco Nacional de Desenvolvimento Econômico e Social - BNDES; e da ação direta de inconstitucionalidade com pedido de liminar n. 1.597-4, proposta perante o Supremo Tribunal Federal em 30 de abril de 1997.

A ação popular, processada sob n. 1997.39.00.12696-8 perante a $1^{\text {a }}$ Vara da Justiça Federal do Pará, pleiteava, em caráter liminar, a não realização do leilão de venda das ações da Companhia Vale do Rio Doce, e, em caráter definitivo, a anulação de todo processo de privatização da companhia. De acordo com as razões aduzidas na respectiva petição inicial, tal processo estaria eivado de vícios e ilegalidades insanáveis, dentre as quais a incompatibilidade, com o direito societário brasileiro, da ação de classe especial que se pretendia atribuir ao Estado. ${ }^{125}$ Em sua contestação, o Banco Nacional de Desenvolvimento Econômico e Social - BNDES alegou que a ação de classe especial encontrava fundamento no art. $8^{\circ}$ da Lei n. 8.031/90 e não conflitava com a lei acionária brasileira. ${ }^{126}$ A medida liminar, embora inicialmente concedida, foi cassada pelo Superior Tribunal de Justiça. A sentença foi proferida pelo juízo monocrático, em 2001, e decretou

\footnotetext{
${ }^{125}$ Textualmente, conforme fls. 54 e 55 dos autos: "Há, ademais, uma sexta ilegalidade. A CVRD, como toda sociedade por ações, tem seu capital dividido em ações cujas espécies são criadas por lei, no caso, a lei n. 6.404, de 15.12.76. Nem o Estatuto Social nem um eventual acordo de acionistas pode criar, numa sociedade por ações, títulos acionários de espécie não prevista em lei. Ora, de acordo com o Edital (itens 1.1 e 3.2.1) 'à União, na qualidade de titular da ação de classe especial ('golden share') da CVRD, será atribuído o direito de veto sobre as seguintes matérias relativas à CVRD, e que deverão obrigatoriamente ser submetidas à Assembléia Geral dos Acionistas'. Segue-se a indicação de sete matérias. Pois bem, esta ação, para a qual se inventou o nome de 'ação de classe especial', não está prevista nos arts. 16 a 19 da Lei de S.A.. Trata-se, pois, de uma criação original do ato convocatório, para além do que permite a lei. Ora, não se tem conhecimento de que o Poder Legislativo haja sido transferido ao BNDES. Com efeito, a lei acionária prevê apenas duas espécies de ações: as ordinárias e as preferenciais. Para umas e outras admite-se (arts. 16 e 18 da lei) a atribuição, pelo Estatuto, de poderes especiais. Sucede que a ação de 'classe especial' prevista no edital não é nem ordinária nem preferencial e atribui aos seus titulares poderes que não estão admitidos nos mencionados artigos da lei de S.A. nem para as ordinárias nem para as preferenciais. Esta ilegalidade é gravíssima porque atinge justamente a garantia especial que pretensamente procurou-se dar à União no sentido de manter um poder especial de controle sobre a CVRD privatizada. Assim, qualquer sócio poderá, ulteriormente, argüindo dita ilegalidade reduzir a pó as pretensas garantias que a União aparentemente se estava reservando. Em suma: houve na criação desta tal 'ação de classe especial' uma gritante ofensa ao princípio da legalidade".

${ }^{126}$ Para suportar essa alegação, o BNDES fez referência e acostou aos autos parecer emitido por Fábio Konder Comparato em resposta a uma consulta feita, em 1996, pela Companhia Energética de São Paulo. Confira-se trecho do parecer transcrito na peça de contestação, a fls. 612 e 613 dos autos: "Se se quiser, portanto, criar aquilo que a prática norte-americana denomina golden share, é preciso construir uma solução que se acomode às normas constantes dos arts. 16 e 18 da Lei n. 6.404/76, seja mantendo, pela falta de norma estatutária, o direito de voto das ações preferenciais, seja trabalhando com classe distinta de ações, tanto ordinárias quanto preferenciais. É possível, assim, reservar para determinadas classes de ações, possuídas direta ou indiretamente pelo Estado, o direito de eleger a maioria dos administradores, submetendo-se à aprovação prévia do órgão administrativo - diretoria ou conselho de administração - todas as matérias julgadas essenciais para a realização da política energética do Estado de São Paulo".
} 
a extinção do processo sem julgamento do mérito, ante o entendimento de que houve perda do objeto e conseqüente carência de interesse processual. ${ }^{127}$

A ação direta de inconstitucionalidade com pedido de liminar n. 1.597-4 foi proposta pelo Partido dos Trabalhadores - PT, pelo Partido Socialista Brasileiro - PSB e pelo Partido Democrático Trabalhista - PDT perante o Supremo Tribunal Federal em abril de 1997. ${ }^{128}$ Nessa ação questionou-se a constitucionalidade - e, indevidamente, a legalidade - de Medida Provisória que atribuiu nova redação ao art. 13 da Lei n. 8.013/90 e dos arts. 39 e 43 do Decreto n. 1.204/94. A respeito desse último dispositivo, alegou-se na petição inicial que a ação de classe especial nele prevista não se subsumia às espécies de ações tipificadas na lei acionária brasileira - Lei n. 6.404/76 - e, por essa razão, estaria caracterizada a violação ao princípio da legalidade inscrito no art. $5^{\circ}$, II da Constituição Federal. $^{129}$

Em julgamento ao pedido liminar dessa ação, em 19 de novembro de 1997, os ministros do Supremo Tribunal Federal, reunidos em sessão plenária, decidiram por unanimidade de votos não conhecer a pretensão relativa ao art. 43. Entenderam os ministros, em síntese, que: $(\boldsymbol{i})$ a ação de classe especial já estava prevista no art. $8^{\circ}$ da Lei n. 8.031/90 e, portanto, não foi introduzida no ordenamento brasileiro por normas regulamentares; (ii) nesse sentido, não houve qualquer violação ao princípio constitucional da legalidade; (iii) a alegada incompatibilidade da ação de classe especial com os preceitos da Lei n. 6.404/76 não deveria ser apreciada em ação direta de constitucionalidade. ${ }^{130}$ Os demais pedidos veiculados pela ação foram conhecidos e providos parcialmente no julgamento da medida liminar. ${ }^{131} \mathrm{O}$ processo ainda tramita perante o Supremo Tribunal Federal. ${ }^{132}$

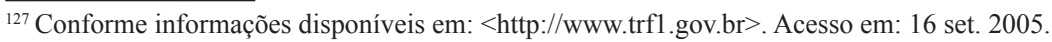

${ }^{128}$ A respeito dessa ação, vide MORAES, Luiza Rangel de. Ação de classe especial - legalidade. Revista de Direito Bancário, do Mercado de Capitais e da Arbitragem, São Paulo, n. 22, p. 129-155, out./dez. 2003.

${ }^{129}$ Vide fls. 8-11 da petição inicial, disponível em: <http://www.stf.gov.br>. Acesso em: 16 set. 2005.

${ }^{130}$ Conforme voto do Ministro Relator Néri da Silveira (especialmente fls. 110 a 114), voto esse que foi acompanhado pelos demais no que tange à alegação de inconstitucionalidade do art. 43 do Decreto n. 1.204/94. (disponível em:<http://www.stf.gov.br>. Acesso em: 16 set. 2005).

${ }^{131}$ Tais pedidos consistiam na suspensão imediata da vigência do art. $1^{\circ}$ da Medida Provisória n. 1.481-48, de 15 de abril de 1997, na parte em que deu nova redação aos arts. 13 da Lei n. 8.031/90 e 39 e 43 do Decreto n. 1.204/90. Segundo se alegou na petição inicial, a alteração promovida pela Medida Provisória seria inconstitucional, pois permitia a alienação, a estrangeiros, de participação em empresas que, de acordo com a Constituição Federal, deveriam ser controladas por sociedades sediadas no Brasil. O Supremo Tribunal Federal não acolheu a suspensão da vigência do artigo, mas determinou que a alienação das ações de sociedades de economia mista referidas no art. 176, $\S 1^{\circ}$ da Constituição Federal deveria ser excluída de seu campo de incidência.

${ }^{132} \mathrm{Em} 03$ de outubro de 2006, o ministro Gilmar Mendes, relator do processo, julgou prejudicada a ação por perda superveniente do objeto, já que as normas cuja constitucionalidade se questionou não estão mais em vigor. Em 17 de outubro, o Partido dos Trabalhadores interpôs agravo regimental contra essa decisão. Conforme informações disponíveis em <http://www.stf.gov.br>. Acesso em: 15 jan. 2007.
} 
Nada obstante tais debates, o processo de privatização da Companhia Vale do Rio Doce foi concluído em maio de 1997 com a venda, à Valepar S.A., das ações ofertadas em leilão. Essa venda foi acompanhada pela reserva, à União Federal, da titularidade de ação de classe especial de emissão da Companhia Vale do Rio Doce e de uma ação preferencial de classe A no capital social da Valepar S.A. ${ }^{133}$

Após a conclusão do processo de privatização da Companhia Vale do Rio Doce, especificamente em setembro de 1997, a Lei n. 8.031/90 foi revogada pela Lei n. 9.491/97. Tal lei manteve, em seu art. $1^{\circ}$, a indicação dos objetivos do Programa Nacional de Desestatização já enunciados pela Lei n. 8.031/90, porém ampliou o alcance do programa de modo a abranger não apenas a alienação de participação societária nas sociedades controladas pela União Federal, mas também a transferência, ao setor privado, da execução de serviços públicos explorados pela União. ${ }^{134}$

Os artigos referentes à ação de classe especial - a saber: arts. $6^{\circ}$, inciso II, alínea “d”; 135 8 $8^{\text {ol36 }}$ e 11, alínea "i"137 - apresentaram redação bastante semelhante aos dispositivos da Lei n. 8.031/90. No entanto, ao tratar dos direitos representados pela ação de classe especial, o art. $8^{\circ}$ referiu-se genericamente a "poderes especiais" ao invés de mencionar apenas o poder de veto. Essa ampliação dos poderes atribuídos à ação de classe especial foi também refletida no Decreto n. 2.594, de 15 de maio de 1998, ${ }^{138}$ que regulamentou a Lei n. 9.491/97.

$\mathrm{Na}$ prática, essa alteração legislativa teve por objetivo incluir, dentre as prerrogativas da ação de classe especial, a de indicar membros do Conselho de Administração das companhias privatizadas. Sob a égide da Lei n. 8.031/90, esse poder, embora já previsto nos estatutos sociais da Companhia Eletromecânica Celma

${ }^{133}$ Conforme Relatório Anual CVRD 1997, disponível em: <http://www.cvrd.com.br>. Acesso em: 16 set. 2005.

${ }^{134}$ A própria terminologia utilizada pela Lei n. 9.491/97 - "desestatização" ao invés de "privatização", expressão empregada pela Lei n. 8.031 - demonstra o maior alcance do programa.

135 “Art. $6^{\circ}$. Compete ao Conselho Nacional de Desestatização: (...) II - aprovar, exceto quando se tratar de instituições financeiras: (...) d) a criação de ação de classe especial, a ser subscrita pela União".

${ }^{136}$ Art. $8^{\circ}$. Sempre que houver razões que justifiquem, a União deterá, direta ou indiretamente, ação de classe especial do capital social da empresa ou instituição financeira objeto da desestatização, que lhe confira poderes especiais em determinadas matérias, as quais deverão ser caracterizadas nos seus estatutos sociais.

${ }^{137}$ Art. 11. Para salvaguarda do conhecimento público das condições em que se processará a alienação do controle acionário da empresa, inclusive instituição financeira incluída no Programa Nacional de Desestatização, assim como de sua situação econômica, financeira e operacional, será dada ampla divulgação das informações necessárias, mediante a publicação de edital, no Diário Oficial da União e em jornais de notória circulação nacional, do qual constarão, pelo menos, os seguintes elementos: (...) i) a indicação, se for o caso, de que será criada ação de classe especial e os poderes nela compreendidos".

${ }^{138}$ Confira-se o teor de seu art. 16: Sempre que houver razões que justifiquem, a União deterá, direta ou indiretamente, ação de classe especial do capital social da empresa ou instituição financeira objeto da desestatização, que lhe confira poderes especiais em determinadas matérias, as quais deverão ser caracterizadas nos seus estatutos sociais". 
e da Empresa Brasileira de Aeronáutica S.A., conforme mencionado acima, não estava diretamente vinculado à detenção da ação de classe especial, encerrando, em vez disso, um poder adicional do Estado.

Ainda em 1997, no âmbito dos debates legislativos para a reforma da lei acionária brasileira, o deputado federal Luiz Carlos Hauly apresentou à Câmara dos Deputados o projeto de Lei n. 3.519, em que sugeriu a inclusão, na Lei n. 6.404/76, de previsão sobre a ação de classe especial. ${ }^{139}$ Conforme justificou o Deputado, provavelmente influenciado pela polêmica havida na privatização da Companhia Vale do Rio Doce, essa medida visava à adequação "da legislação societária às normas do Plano Nacional de Desestatização". ${ }^{140}$

A proposta foi aprovada, com modificações substanciais, ${ }^{141}$ pelos órgãos legislativos e, após a sanção presidencial, foi refletida na Lei n. 10.303, de 31 de outubro de 2001. Por força dessa lei, o art. 17 da lei acionária brasileira, que trata das vantagens e preferências das ações preferenciais, passou a contar com o seguinte parágrafo:

\begin{abstract}
$\S 7^{\mathbf{0}} \quad$ Nas companhias objeto de desestatização poderá ser criada ação preferencial de classe especial, de propriedade exclusiva do ente desestatizante, à qual o estatuto social poderá conferir os poderes que especificar, inclusive o poder de veto às deliberações da Assembléia-Geral nas matérias que especificar.
\end{abstract}

\footnotetext{
${ }^{139}$ Tratava-se do seguinte artigo: "Art. 15. As ações, conforme a natureza dos direitos ou vantagens que confiram a seus titulares, são ordinárias, de fruição ou especiais. (...) § $2^{\circ} \mathrm{A}$ ação de classe especial somente será emitida e atribuída a titular específico, por sociedade objeto de desestatização, nos termos da legislação pertinente, cujos estatutos sociais definirão as matérias sobre as quais terão poderes exclusivos". Íntegra do projeto de lei e de sua justificação obtida junto ao Gabinete do Deputado Luiz Carlos Hauly. Durante o trâmite legislativo, apensou-se tal projeto ao projeto de Lei n. 3.115, de 1997.

${ }^{140}$ Segundo constou da justificação ao projeto de Lei n. 3.115, de 1997, apresentada pelo Deputado Hauly em 14 de maio de 1997: "A Lei n. 8.031, de 12 de abril de 1990, que cria o Programa Nacional de Desestatização e dá outras providências, previu a criação de ações de classe especial, que confeririam à União poder de veto em determinadas matérias, as quais deveriam ser caracterizadas nos estatutos sociais das empresas privatizadas. (....) Ocorre que essa previsão de criação de ações de classe especial tem sido questionada sob o argumento de que 'essas ações não existem na legislação brasileira' e que 'seria preciso criar essa espécie nova de ação, para depois se dizer que o estatuto da companhia privatizada deveria atribuir essas ações à União. Segundo o advogado e professor Fábio Comparato (entrevista publicada em a Gazeta do Povo, edição de 4 de maio de 1997): 'isso não foi feito. O que pode acontecer é que após a pretendida privatização da Vale do Rio Doce, qualquer acionista peça em juízo a declaração de nulidade ou inexistência dessas ações em poder da União. Esse famoso poder de controle que a União guardaria para si é reduzido a pó'. Para suprir a alegada lacuna na legislação específica e evitar futuros litígios com base nesse argumento é que se apresenta esse projeto de lei (...)". (Diário do Senado Federal, edição de 18 de abril de 2001, p. 06140-06141).

${ }^{141}$ Na proposta do deputado Hauly a "ação de classe especial" era qualificada como espécie de ação ("ação especial”), ao lado das ações ordinárias e das ações de fruição. Na Lei n. 10.303/01, o tratamento é diverso, representando classe de ações preferenciais.
} 
Note-se que, segundo esse dispositivo, a chamada "ação de classe especial" deve ser qualificada como ação preferencial. ${ }^{142}$ Tal qualificação - inexistente na Lei n. 9.491/97 e no Decreto n. 2.594/98, ainda vigentes - assume extrema importância para análise do instrumento no Brasil.

Com a reforma da lei acionária e a conseqüente introdução desse dispositivo no ordenamento brasileiro, outras normas passaram a mencionar a "ação preferencial de classe especial". É o caso do Regulamento do Novo Mercado da Bolsa de Valores do Mercado de São Paulo. ${ }^{143}$ Segundo seu item 2.1, as "ações preferenciais de classe especial que tenham por fim garantir direitos políticos diferenciados, sejam intransferíveis e de propriedade do ente desestatizante" não devem ser consideradas ações em circulação de uma companhia. Além disso, de acordo com seu item 3.1, "vii”, a existência de ação preferencial de classe especial não viola a exigência de emissão exclusiva de ações ordinárias, condição para adesão de uma companhia ao Novo Mercado.

A reforma da lei acionária não ocasionou, até o momento, a completa adaptação dos estatutos das companhias privatizadas que emitiram e ainda mantêm ${ }^{144}$ ações de classe especial.

Com efeito, o vigente estatuto social ${ }^{145}$ da Empresa Brasileira de Aeronáutica S.A. ainda prevê que a ação de classe especial é da espécie ordinária, regida apenas pela Lei n. 9.491/97. ${ }^{146}$ Os direitos a ela inerentes são o veto nas deliberações que envolvam matérias consideradas estratégicas e a eleição de um membro do Conselho de Administração da Companhia. Conforme os artigos estatutários pertinentes:

\begin{abstract}
"Art. 6” O capital social da Companhia, subscrito e totalmente integralizado, é de $\mathrm{R} \$ 4.771 .726 .054,66$, dividido em 738.611.819 ações ordinárias e uma ação ordinária de classe especial $\left(\operatorname{art.} 9^{\circ}\right)$.
\end{abstract}

\footnotetext{
${ }^{142}$ A respeito, vide CARVALHOSA, Modesto Souza Barros; EIZIRIK, Nelson. A nova lei das S.A. São Paulo: Saraiva, 2002. p. 114.

${ }^{143}$ Regulamento disponível em: <http://www.bovespa.com.br>. Acesso em: 16 set. 2005.

${ }^{144}$ A Companhia Eletromecânica Celma, atualmente denominada GE Celma S.A., é a única que não mais apresenta ação de classe especial.

145 Tal como aprovado pela Assembléia Geral Extraordinária realizada em 31 de março de 2006 (disponível em: $<$ http://www.embraer.com.br>. Acesso em: 16 jan. 2007). Nessa data, foi aprovada reestruturação societária da Embraer com o objetivo de simplificar a estrutura de capital da companhia, criando-se as condições para sua adesão ao Novo Mercado, segmento de listagem da Bovespa. A reformulação do estatuto social aprovada nessa ocasião inovou a disciplina da ação ordinária de classe especial de emissão da companhia, fixando procedimentos bastante detalhados para o exercício dos poderes a ela inerentes.

${ }^{146}$ A rigor, mesmo antes da reforma promovida pela Lei n. 10.303/01, a ação de classe especial de emissão da Empresa Brasileira de Aeronáutica S.A. poderia ser tida por incompatível com a lei acionária. Isso porque se trata de companhia aberta que apresenta classe de ações ordinárias, em desacordo com o disposto no caput do art. 16 da mencionada lei. Cumpre observar que, na reestruturação societária realizada em março de 2006, optou-se por manter a ação sob essa espécie, provavelmente para não romper com as práticas corporativas adotadas pela companhia desde a emissão da ação de classe especial.
} 
$\S \mathbf{1}^{\mathbf{0}}$ O capital será sempre dividido exclusivamente em ações ordinárias, vedada a emissão de ações preferenciais.

§ 20 A classe especial da ação da União compreenderá sempre uma única ação, que preservará todas as suas prerrogativas enquanto for detida pela União (conforme art. $8^{\circ}$ da Lei n. 9.491/97)".

“Art. 90 A ação ordinária de classe especial confere à União poder de veto nas seguintes matérias:

i. mudança de denominação da Companhia ou de seu objeto social;

ii. alteração e/ou aplicação de logomarca da Companhia;

iii. criação e/ou alteração de programas militares, que envolvam ou não a República Federativa do Brasil;

iv. capacitação de terceiros em tecnologia para programas militares;

v. interrupção de fornecimento de peças de manutenção e reposição de aeronaves militares;

vi. transferência do controle acionário da Companhia;

vii. quaisquer alterações (i) às disposições deste artigo, do art. 4, do caput do art. 11, dos arts. 12,15 e 16, do inciso III do art. 19 , dos parágrafos $1^{\circ}$ e $2^{\circ}$ do art. 28 , do inciso X do art. 34, do inciso XII do art. 40 ou do Capítulo VII; ${ }^{147}$ ou ainda (ii) de direitos atribuídos por este Estatuto à ação de classe especial.

§ $\mathbf{1}^{\mathbf{0}}$ Estará sujeita à prévia aprovação da União, na qualidade de detentora da ação ordinária de classe especial, a realização da oferta pública de aquisição de ações referida no art. 55 do presente estatuto. ${ }^{148}$

§ $2^{\mathbf{0}}$ Observado o disposto na Lei n. 6.404/76 e no art. 19, inciso III, deste estatuto, as matérias elencadas no presente artigo estarão sujeitas à deliberação do Conselho de Administração da Companhia, observando-se o seguinte procedimento:

i. a matéria será objeto de deliberação do Conselho de Administração.

ii. se aprovada pelo Conselho de Administração, o

\footnotetext{
${ }^{147}$ Tais dispositivos dizem respeito a: (i) art. $4^{\circ}$ : princípios que regem a organização e o funcionamento da companhia; (ii) art. 11, caput: definição de acionistas brasileiros; (iii) art. 12: definição de acionistas estrangeiros; (iv) art. 15: fixação de limites para o exercício do direito de voto para acionistas brasileiros e para acionistas estrangeiros; (v) art. 16: regras para o exercício do direito de voto em Assembléia; (vi) art. 19, inciso III: competência privativa da Assembléia Geral para deliberar sobre as matérias sujeitas a veto da União; (vii) art. $28, \S \S 1^{\circ}$ e $2^{\circ}$ : direito de nomeação de membros do Conselho de Administração, em votação em separado, atribuído à União e aos empregados da companhia; (viii) art. 34, inciso X: competência do Conselho de Administração de apreciar as matérias sujeitas ao poder de veto da União; (ix) art. 40, inciso XII: competência da Diretoria de submeter à apreciação do Conselho de Administração as matérias sujeitas a veto da União; e ( $\boldsymbol{x}$ ) Capítulo VII: registro de companhia aberta e novo mercado.

${ }^{148}$ Trata-se de oferta pública a ser realizada por acionista ou grupo de acionista que se torne titular de $35 \%$ do total de ações de emissão da companhia ou de direitos a ela relativos.
} 
presidente daquele órgão notificará o membro eleito pela união para que esta exerça seu direito de veto ou se manifeste favoravelmente à matéria, dentro do prazo de 30 dias a contar do recebimento da referida notificação.

iii. decorrido o prazo referido no inciso II, acima, será realizada nova reunião do Conselho de Administração para: (i) reconsiderar a deliberação caso a União tenha exercido o seu direito de veto; ou (ii) ratificar a deliberação, caso a União tenha se manifestado favoravelmente ou não tenha proferido qualquer manifestação no prazo indicado acima. iv. se a deliberação for ratificada pelo Conselho de Administração, a matéria, nos casos em que a legislação assim exija, será submetida à aprovação da Assembléia Geral, na qual a União poderá ainda exercer o poder de veto nos termos do presente artigo.

$\S 3^{\mathbf{0}}$ Sem prejuízo do procedimento estabelecido no $\S$ $2^{\circ}$ acima, todas as matérias sujeitas a veto da União, na qualidade de titular da ação ordinária de classe especial, a serem deliberadas no Conselho de Administração, deverão adicionalmente ser objeto de notificação prévia da Companhia ao Ministério da Fazenda, a ser feita concomitantemente com a notificação mencionada no inciso II acima, para pronunciamento dentro do prazo de 30 dias a contar do recebimento da notificação referida no inciso II, acima."

"Art. 28 O Conselho de Administração será composto de 11 membros e respectivos suplentes, todos acionistas, eleitos pela Assembléia Geral, com mandato unificado de 2 anos, permitida a reeleição.

$\S \mathbf{1}^{\mathbf{0}}$ A União, na qualidade de titular da ação de classe especial, terá direito de eleger um membro do Conselho de Administração e respectivo suplente.

(...)."

No caso da Companhia Vale do Rio Doce, a situação é bastante diversa. De acordo com o vigente Estatuto Social da companhia, ${ }^{149}$ as seis ações de classe especial atualmente detidas pela União Federal incluem-se dentre as preferenciais, conforme prevê a lei, e encerram os seguintes direitos: (i) direito de voto nas deliberações sociais, exceto na eleição dos membros do Conselho de Administração; (ii) direito de participar, com prioridade, na distribuição de lucros; (iii) veto em deliberações que recaíam sobre matérias tidas como relevantes para os interesses do Estado brasileiro. Confiram-se os respectivos dispositivos do Estatuto Social:

\footnotetext{
${ }^{149}$ Estatuto Social aprovado em Assembléia Geral Extraordinária realizada em 27 de abril de 2006, disponível em $<$ http://www.cvrd.com.br>. Acesso em: 16 set. 2006.
} 
“Art. 5" O capital social é de R $\$ 19.492 .400 .974,56$, correspondendo a 2.459.657.058 ações escriturais, sendo R\$ 9.007.032.395,62, divididos em 1.499.898.858 ações ordinárias e R \$ 10.485.368.578,94, divididos em 959.758.200 ações preferenciais classe 'A', incluindo 06 (seis) de classe especial, todas sem valor nominal.

$\S 1^{\circ}$ As ações são ordinárias e preferenciais. As ações preferenciais são das classes 'A' e 'especial'.

$\S 2^{\circ}$ As ações preferenciais da classe especial pertencerão exclusivamente à União Federal. Além dos demais direitos que lhe são expressa e especificamente atribuídos no presente Estatuto Social, as ações preferenciais de classe especial terão os mesmos direitos das ações preferenciais classe "A".

$\S 3^{\circ}$ Cada ação ordinária, cada ação preferencial classe 'A' e cada ação preferencial de classe especial dá direito a um voto nas deliberações das Assembléias Gerais, respeitado o disposto no $\S 4^{\circ}$ a seguir.

$\S 4^{\circ}$ As ações preferenciais das classes "A" e especial terão os mesmos direitos políticos das ações ordinárias, com exceção do voto para eleição dos membros do Conselho de Administração, ressalvado o disposto nos $\S \S 2^{\circ}$ e $3^{\circ}$ do art. 11 a seguir, bem como o direito de eleger e destituir um membro do Conselho Fiscal e o respectivo suplente.

$\S 5^{\circ}$ Os titulares das ações preferenciais das classes "A" e especial terão direito de participar do dividendo a ser distribuído, calculado na forma do Capítulo VII, de acordo com o seguinte critério:

a) prioridade no recebimento dos dividendos mencionados neste $\S 5^{\circ}$ correspondente a (i) no mínimo $3 \%$ do valor do patrimônio líqüido da ação, calculado com base nas demonstrações financeiras levantadas que serviram como referência para o pagamento dos dividendos; ou (ii) $6 \%$ calculado sobre a parcela do capital constituída por essa classe de ação, o que for maior entre eles;

b) direito de participar dos lucros distribuídos, em igualdade de condições com as ações ordinárias, depois de a estas assegurado dividendo igual ao mínimo prioritário estabelecido em conformidade com a alínea "a" acima; e

c) direito de participar de eventuais bonificações, em igualdade de condições com as ações ordinárias, observada a prioridade estabelecida para a distribuição de dividendos. $\S 6^{\circ}(\ldots)$.

"Art. $7^{\circ}$ A ação de classe especial terá direito de veto sobre as seguintes matérias:

i. alteração da denominação social;

ii. mudança da sede social;

iii. mudança no objeto social no que se refere à exploração mineral; 
iv. liquidação da sociedade;

v. alienação ou encerramento das atividades em qualquer uma ou do conjunto das seguintes etapas dos sistemas integrados de minério de ferro da sociedade: (a) depósitos minerais, jazidas, minas; (b) ferrovias; (c) portos e terminais marítimos;

vi. qualquer modificação dos direitos atribuídos às espécies e classes das ações de emissão da sociedade previstos neste Estatuto Social;

vii. qualquer modificação deste art. $7^{\circ}$ ou de quaisquer dos demais direitos atribuídos por este Estatuto Social às ações de classe especial."

Embora as Leis n. 9.491/97 e n. 10.303/01 tratem da emissão de ações de classe especial por companhias "objeto de desestatização" - cujos principais exemplos são justamente a Empresa Brasileira de Aeronáutica S.A. e a Companhia Vale do Rio Doce - o mecanismo é também utilizado no Brasil por sociedades anônimas fora do contexto das privatizações. ${ }^{150}$ Nesses casos, o instrumento desempenha funções bastante diversas da proteção dos interesses estratégicos do Estado.

Para ilustrá-las, cumpre citar a aplicação do modelo das ações de classe especial realizada em duas sociedades anônimas brasileiras: Companhia Brasileira de Liquidação e Custódia e Companhias de Bicicletas Caloi S.A.

Na Companhia Brasileira de Liquidação e Custódia - CBLC, responsável pela prestação dos serviços de compensação, liquidação, custódia e depósito no mercado de capitais brasileiro, a ação preferencial de classe especial foi atribuída à Bolsa de Valores de São Paulo - Bovespa como forma de assegurar a continuidade da prestação daqueles serviços e permitir certa ingerência nessa prestação.

Além de direitos patrimoniais, a ação confere à Bolsa de Valores de São Paulo o direito de eleger membros do Conselho de Administração da companhia e de aprovar determinadas matérias por votação em separado. Nos termos do Estatuto Social:151

\footnotetext{
${ }^{150}$ Recentemente, por ocasião da venda de ações de emissão da Embratel Participações S.A. pelo grupo americano MCI à companhia mexicana Teléfonos de México S.A., o Governo brasileiro cogitou a adoção do instrumento "ação de classe especial", nos moldes previstos nos estatutos sociais da Empresa Brasileira de Aeronáutica S.A. e da Companhia Vale do Rio Doce, tal como transcritos acima. Cf. Comunicado do Ministério das Comunicações datado de 13 de maio de 2004, disponível em $<$ http://mc.gov.br $>$. Acesso em: 16 set. 2005. Nesse caso, a adoção da ação de classe especial - embora não estivesse vinculada a um processo de privatização - também se destinava à proteção dos interesses estatais. De fato, a empresa que emitiria essa ação - Star One - é controlada indireta da Embratel Participações S.A. e suas atividades consistem na operação de sistemas de satélite, em que trafegam as comunicações das Forças Armadas e sinais de televisão brasileiros.

${ }^{151}$ Estatuto Social aprovado em Assembléia Geral Extraordinária realizada em 29 de abril de 2003, com alterações no art. $5^{\circ}$ aprovadas em Assembléia Geral Extraordinária realizada em 14 de abril de 2005, disponível em: $<$ http://www.cblc.com.br>. Acesso em: 16 set. 2006.
} 
“Art. 5 O capital social subscrito e integralizado é de R\$ 203.000.000,00, dividido em 81.501 ações ordinárias nominativas, sem valor nominal, e 1 ação preferencial de 'classe especial' ('golden share'), também sem valor nominal.

$\S 1^{\circ}$ A ação preferencial de "classe especial" de que trata o caput deste artigo pertence à acionista Bolsa de Valores de São Paulo, na qualidade de acionista instituidora, à qual serão conferidos os seguintes direitos:

i. direito de voto em separado para eleição de 2 (dois) membros efetivos e 1 (um) membro suplente do Conselho de Administração da CBLC;

ii. direito de aprovar, por votação em separado, as seguintes matérias:

a. alteração da denominação social (art. $1^{\circ}$ deste estatuto);

b. mudança da sede social (art. $2^{\circ}$ deste estatuto);

c. mudança do objeto social (art. $3^{\circ}$ deste estatuto);

d. participação da CBLC em outras sociedades sempre que se fizer necessária a alteração estatutária prevista no art. $3^{\circ}$, inciso $\mathrm{X}$ deste estatuto; ${ }^{152}$

e. liquidação, fusão, cisão ou incorporação da CBLC;

f. alterações nos direitos ou deveres dos Agentes de Compensação (arts. 31 e 32 deste estatuto); e

g. extinção ou modificação de qualquer direito atribuído à ação preferencial de 'classe especial'.

iii. prioridade no reembolso de capital, sem prêmio."

No caso da Bicicletas Caloi S.A., o modelo da ação preferencial de classe especial foi aplicado, em 1998, em contexto e com intuito bastante diverso: recuperação de empresas em crise. ${ }^{153}$ Atribuiu-se uma ação preferencial à sociedade encarregada da

\footnotetext{
${ }^{152}$ Dispõe o mencionado inciso X do art. $3^{\circ}$ do Estatuto Social: “Art. $3^{\circ} \mathrm{A}$ CBLC terá por objeto: (...) X. participar, sujeita à aprovação dos órgãos reguladores, no capital de outras sociedades, sediadas no país ou no exterior, seja na qualidade de sócia, acionista ou quotista, sendo exigida referência expressa neste estatuto, sempre que envolver investimentos superiores a $10 \%$ do capital social da sociedade participada;"

${ }^{153}$ Sobre a utilização da golden share como instrumento de recuperação, vide SALOMÃO FILHO, Calixto. $O$ novo direito societário. 2 ed. São Paulo: Malheiros, 2002. p. 114-115, em especial o seguinte trecho: "Esse instrumento é e tem sido recentemente utilizado como eficaz meio de recuperação de empresas em dificuldades. Nesses casos, freqüentemente a imagem do controlador encontra-se tão desgastada que para a obtenção de crédito é fundamental não apenas uma mudança da administração, mas uma mudança de controle. A golden share fornece então instrumento eficaz e relativamente indolor para o controlador, já que ao mesmo tempo em que garante que esse não possa influir na administração, perdendo virtualmente todos os seus poderes, não implica perda do 'patrimônio' do controlador, i.e., diluição ou redução de sua participação no capital da companhia". Note-se que embora o trecho não faça referência expressa a Bicicletas Caloi S.A., a descrição aplica-se perfeitamente ao caso.
} 
gestão temporária da companhia, com prerrogativas especiais em relação às demais ações de sua emissão. Confira-se o teor do art. $6^{\circ}$ do Estatuto Social: ${ }^{154}$

“Art. 60 Ocapitalsocial,totalmentesubscritoeintegralizado, é de 67.063.033,80, representado por 72.409.994.474 ações, sem valor nominal, sendo: 61.748.576.923 ações ordinárias; 52.777 .900 ações preferenciais da classe 'A', 10.608.639.650 ações preferenciais da classe 'B' e 1 ação preferencial da classe ' $\mathrm{C}$ ', todas elas escriturais, mantidas e controladas em contas de depósito de ações escriturais em instituição depositária autorizada a manter serviços de ações, sem emissão de certificados, de conformidade com os arts. 34 e 35 e respectivos parágrafos da Lei n. 6.404/76. As ações preferenciais classe ' $\mathrm{A}$ ' e ' $\mathrm{B}$ ' terão direitos referidos no parágrafo deste artigo, e a preferencial classe ' $\mathrm{C}$ ' terá direito a voto e de participação nos lucros em igualdade de condições com as ações ordinárias, tendo ainda o direito de:

i. eleger metade mais um dos membros do Conselho de Administração da Companhia, em Assembléia Especial;

ii. vetar quaisquer deliberações de Assembléia Geral que impliquem em qualquer modificação do Estatuto Social, que direta ou indiretamente:

a. alterem os direitos ou poderes dessa ação preferencial da classe ' $\mathrm{C}$ '; ou

b criem qualquer outra classe ou espécie de ações com direitos políticos favorecidos ou outorguem direitos políticos favorecidos a classe ou espécie de ação já existente que restrinjam direta ou indiretamente, os poderes ora conferidos à ação preferencial dessa classe "C"; ou

c. possibilitem o exercício de opção de ações objeto do Contrato de Gestão Empresarial firmado em 29 de julho de 1997, com a MGDK e Associados S/C Ltda., ou

d. modifiquem os poderes e atribuições dos órgãos de administração ou criem novos órgãos de administração afetando, direta ou indiretamente, os poderes conferidos aos atuais órgãos de administração.

Essa ação preferencial será reconversível em ação ordinária quanto ao (sic) término ou rescisão do Contrato de Gestão Empresarial com a MGDK e Associados S/C Ltda."

Como se observa, a ação preferencial de classe "C", assim disciplinada, permitiu a ampliação dos poderes e atribuições da administração da sociedade e a limitação das prerrogativas do então acionista controlador.

\footnotetext{
${ }^{154}$ Estatuto Social apresentado para a Comissão de Valores Mobiliários no Relatório IAN - Informações Anuais, data-base 31 de dezembro de 1998, disponível em: <http://www.cvm.gov.br>. Acesso em: 16 set. 2005.
} 
A adoção do modelo da ação de classe especial por essas duas companhias evidencia as potencialidades do instrumento no âmbito do direito privado. Há a ampliação do alcance do mecanismo, originalmente criado para permitir a intervenção estatal em companhias privatizadas.

\subsection{Síntese comparativa}

As diferentes experiências relatadas neste artigo demonstram que a expressão "golden share" designa, genericamente, os mecanismos de Direito societário criados a partir do modelo de privatizações britânico para permitir ingerência qualitativamente diferenciada nas deliberações e negócios sociais por pessoa que não figura como titular da maioria das ações do capital da companhia ou de participação minoritária expressiva.

No entanto, há diferenças substanciais entre os diversos mecanismos de direito societário apresentados sob a denominação genérica de golden share.

Realmente, embora em grande parte dos ordenamentos a golden share seja representada por título acionário correspondente a uma unidade do capital social - como ocorre no Reino Unido, França e Brasil -, há casos - dentre os quais, o da Itália - em que o instrumento assume a forma de mera cláusula estatutária, sem a corporificação dos respectivos poderes em um título acionário.

Ademais, as golden shares podem distinguir-se quanto à sede da disciplina que as instituiu. ${ }^{155}$ No Reino Unido, por exemplo, tal sede é, em geral, estatutária. ${ }^{156}$ Em virtude do amplo alcance da autonomia privada no Direito britânico, basta a inserção do regramento aplicável nos atos constitutivos da companhia, não sendo necessária previsão legal. Por outro lado, nos países de sistema jurídico continental europeu, é imprescindível que a introdução da golden share seja respaldada por lei, seja ela de Direito Público, no que toca às companhias objeto de privatização, seja na legislação acionária, no que se refere às companhias em geral. Isso não significa, porém, que se exija lei específica para o tema. É suficiente que a legislação societária contemple mecanismos que permitam a conjugação dos poderes especiais próprios às golden shares.

Diferenciam-se também as golden shares quanto aos poderes que conferem ao respectivo titular. Como explicam Grundmann e Möslein, as golden shares encerram direitos de duas ordens, relativos: $(\boldsymbol{i})$ ao processo de decisão dos órgãos da

\footnotetext{
${ }^{155}$ A respeito, vide: GRUNDMANN, Stefan; MÖSLEIN, Florian. Golden shares: state control in privatised companies: comparative law, European law and policy aspects. Apr. 2003. Disponível em: <http://ssrn.com/ abstract $=410580>$. Acesso em 16 jul. 2003, p. 2.

${ }^{156}$ Há poucos casos em que as golden shares encontraram previsão legal. Referência é feita ao British Aerospace Act, datado de 1980, e ao Airports Act, datado de 1986. Cf. RODRIGUES, Nuno Cunha. Golden shares: as empresas participadas e os privilégios do Estado enquanto acionista minoritário. Coimbra: Coimbra Editora, 2004. p. 267.
} 
companhia, especialmente a Assembléia Geral; e (ii) à ingerência na estrutura acionária da companhia. ${ }^{157}$

Dentre os primeiros, encontram-se: a aprovação de alterações estatutárias; o poder de veto em determinadas deliberações sociais; a aprovação da disposição de ativos da companhia; ${ }^{158}$ e a nomeação de administradores e membros do Conselho Fiscal. Tais poderes, como se pode notar, estão presentes em todas as manifestações de golden shares analisadas neste artigo.

Porém, o mesmo não ocorre com o poder de ingerência sobre a estrutura acionária da companhia. Traduzido na prerrogativa de impedir a aquisição, por parte de uma pessoa ou de grupo organizado de pessoas, de número de ações que ultrapassasse certo limite, esse poder não foi estabelecido no Brasil senão no caso da Empresa Brasileira de Aeronáutica - Embraer, ${ }^{159}$ tendo sido contemplado com freqüência no Reino Unido, França e Itália.

Por fim, distinguem-se as golden shares conforme o titular dos poderes a elas inerentes: o próprio Estado, na maior parte das vezes, ou um agente privado alheio à perspectiva da intervenção do Estado na economia, como nos casos da Bicicletas Caloi S.A. e Companhia Brasileira de Liquidação e Custódia, acima relatados.

\section{As golden shares e o Direito Privado}

A adoção das golden shares, nas formas descritas acima, provocou questionamentos sobre a adequação e, principalmente, sobre a licitude desse instrumento.

No âmbito do Direito Público, por exemplo, discutiu-se a efetividade das golden shares como mecanismo destinado a reservar ao Estado certa ingerência nas companhias privatizadas, após a transferência de seu controle ao setor privado. Questionouse, ademais, o sentido e o alcance do interesse público cuja presença se reputava necessária para adoção do instrumento.

Ainda no âmbito do Direito Público, examinou-se a compatibilidade das golden shares com princípios fundamentais de Direito Constitucional econômico, como a

\footnotetext{
${ }^{157}$ GRUNDMANN, Stefan; MÖSLEIN, Florian. Golden shares-state control in privatised companies: comparative law, European law and policy aspects. Apr. 2003. Disponível em: $<$ http://ssrn.com/abstract=410580 $>$. Acesso em: 16 jul. 2003 , p. 3.

${ }^{158}$ Como notam Stefan Grundmann e Florian Möslein tais direitos assumem tanto a forma de autorização prévia como de posterior cancelamento do ato (Id. Ibid., p. 3).

${ }^{159} \mathrm{O}$ art. $9^{\circ}$, inciso VI, do estatuto da companhia prevê que a ação de classe especial terá poder de veto na transferência do controle acionário. Essa previsão, no entanto, se mostra contrária à técnica societária. Isso porque a transferência de controle acionário da Embraer opera-se na esfera patrimonial dos acionistas controladores da companhia e não se inclui dentre as competências dos órgãos dela própria, como faz crer o art. $9^{\circ}$. Além disso, a Embraer é uma companhia aberta e, por essa razão, não se admite a imposição de limites à circulação de suas ações.
} 
liberdade de iniciativa e a garantia da propriedade privada. Verificação similar, desta vez em relação ao princípio da livre circulação de capitais e da liberdade de estabelecimento, pode ser encontrada no plano do Direito Comunitário, como relatado acima.

No entanto, em que pese a importância de todos esses questionamentos para a compreensão completa do tema, deve-se reconhecer que é no âmbito do Direito Privado que emergem as mais relevantes indagações acerca da licitude das golden shares e da conveniência econômica de sua utilização. ${ }^{160}$

Argumenta-se que as golden shares violariam regras e princípios centrais de direito societário, como (i) a proporcionalidade entre direitos e participação acionária (princípio enunciado como "one share one vote"), (ii) a impessoalidade da participação acionária, (iii) a igualdade entre acionistas, (iv) a deliberação por maioria, (v) a livre circulação dos títulos acionários, e (vi) a tipicidade das espécies e classes de ações. Por contrariar essas regras e princípios, tidos como essenciais ao regime das sociedades anônimas, há quem defenda, inclusive, que as golden shares descaracterizariam esse tipo societário. ${ }^{161}$

Esses questionamentos demandam a releitura deste tema central para o direito societário: a tipicidade das sociedades anônimas. É preciso inicialmente definir quais elementos compõem o tipo "sociedade anônima". Identificados esses elementos, cumpre cotejá-los com a estrutura das golden shares. Somente após essa tarefa, pode-se concluir se esse novo instrumento realmente importa, ou pode importar, a descaracterização daquele tipo societário ${ }^{162}$.

\footnotetext{
${ }^{160}$ A respeito, vide: GRUNDMANN, Stefan; MÖSLEIN, Florian. Golden shares - state control in privatised companies: comparative law, European law and policy aspects. Apr. 2003. Disponível em: <http://ssrn.com/ abstract $=410580>$. Acesso em: 16 jul. 2003; RUTABANZIBWA, Audax Peter. What is golden in the golden share? Company law implications of privatisation. Company Lawyer, London, n. 17, fasc. 2, p. 40-45, 1996.

${ }^{161}$ Tais como: CARREAU, Dominique; TREUHOLD, Robert. Privatisations, droit boursier et pratiques des marchés. Revue des Sociétés, Paris, n. 112, p. 1-23, 1994. p. 12; CIRENEI, Maria Teresa. op. cit., p. 821-823; JAEGER, Pier Giusto. Privatizzazioni; "public companies"; problemi societari. Giurisprudenza Commerciale, Milano, n. XXII, parte I, fasc. 1, p. 5-19, 1995, p. 6-10; IRTI, Natalino. L'ordine giuridico del mercato. 4. ed. Bari: Editori Laterza, 2001. p. 113; LIBONATI, Berardino. La faticosa "accelerazione" delle privatizzazioni. Giurisprudenza Commerciale, Milano, n. XXII, parte I, fasc. 1, p. 20-76, 1995. p. 67; MINERVINI, Gustavo. Contro il diritto speciale delle imprese pubbliche "privatizzate". Rivista delle Società, Milano, n. 39, fasc. 4, p. 740-747, luglio/agosto 1994. p. 741 e 746; SALERNO, Luigi. Golden shares. Interessi publici e modelli societari tra diritto interno e disciplina comunitaria. Diritto del Commercio internazionale, Milano, n. XVII, p. 671-704, 2002. p. 698-699; SODI, Jacopo. op. cit., p. 393 e 408; SPADA, Paolo. Autorità e libertà nel diritto della società per azioni. Rivista di Diritto Civile, Padova, n. XLII, fasc. 6, p. 703-719, 1996, p. 714; e OPPO, Giorgio. Privatizzazioni: aspetti privatistici. In: MARASÀ, Giorgio (Org.). Profili giuridici delle privatizzazioni. Torino: G. Giappichelli Editore, 1997. p. 22-23.

${ }^{162}$ Interessante notar que a verificação aqui empreendida - acerca da compatibilidade de uma nova figura de direito societário com a disciplina das sociedades anônimas - encontra precedentes no Direito brasileiro. Basta lembrar, por exemplo, os estudos realizados após a edição da Lei n. 6.404/76 a respeito do capital autorizado. Referência é feita a: LEÃES, Luis Gastão Paes de Barros. A sociedade anônima de capital autorizado não é novo tipo social. In: Direito comercial: textos e pretextos. São Paulo: José Bushatsky Editor, 1976, p. 267-281;
} 
Ainda no âmbito do Direito Privado, e em estreita relação com o exame da conveniência econômica da adoção das golden shares, discute-se o impacto das golden shares no funcionamento do mercado de valores mobiliários e sua influência sobre o preço das ações da companhia emissora negociadas nesse mercado.

Há debates, também, sobre a garantia do direito de recesso aos acionistas dissidentes em relação à emissão da golden share ou ao exercício dos direitos a ela inerentes, e sobre os efeitos das golden shares sobre a definição do interesse social. Indaga-se, a esse respeito, se as golden shares importariam a subordinação do interesse social a interesses políticos e econômicos estranhos à companhia.

As análises desenvolvidas no item 2 deste artigo mostram que as golden shares resultam de um importante trabalho de "engenharia jurídica", nos dizeres de Ascarelli, iniciado no Reino Unido e posteriormente empreendido em diversos países, inclusive no Brasil.

Por outro lado, as questões levantadas neste item 3 indicam que é também necessário estudar o modo como essa nova "máquina" articula-se com a engrenagem mais ampla da disciplina jurídica das companhias e do Direito Privado. Essa tarefa, no entanto, ultrapassa o escopo deste artigo, dedicado apenas a relatar origem e ao desenvolvimento das golden shares. ${ }^{163}$

São Paulo, fevereiro de 2007.

\section{Referências}

ALBUQUERQUE, Pedro de; PEREIRA, Maria de Lurdes. As "golden shares" do Estado português em empresas privatizadas: limites à sua admissibilidade e exercício. Coimbra: Coimbra Editora, 2006.

ASCARELLI, Tullio. Varietà di titoli di credito e investimento. In: PROBLEMI giuridici. t. II. Milano: Dott. A. Giuffrè Editore, 1959. t. II. p. 685-702.

BELVISO, Francesco. La nomina da parte dello Stato degli amministratori delle società privatizzate (art. 2, comma $1^{\circ}$, lett. d legge n. 474/1994). In: MARASÀ, Giogio (Org.). Profili giuridici delle privatizzazioni. Torino: G. Giappichelli Editore, 1997. p. 103-110.

BORDE, Dominique; PONCELET, Aline. Le noveau programme de privatisation français de 1993:

e Tavares Guerreiro, José Alexandre. Regime jurídico do capital autorizado. São Paulo, 1983. Dissertação (mestrado) - Departamento de Direito Comercial da Faculdade de Direito da Universidade de São Paulo, p. 72-76.

${ }^{163}$ Essa tarefa foi um dos objetivos da tese de doutorado da Autora, mencionada no preâmbulo deste artigo. Confira-se, a respeito, os capítulos 3 a 5 da tese As golden shares no Direito brasileiro. São Paulo, 2007. 
une importante evolution des techniques de mise en vente sur les marchés financiers. Rivista delle Società, Milano, n. 39, fasc. 1-2, p. 269-302, genn./apr. 1994. (Versão preliminar do artigo publicada em Revue de droit des affaires internationales, Paris, n. 8, p. 943-957, 1993).

CANTIDIANO, Luiz Leonardo. Reforma da lei das S.A. comentada. Rio de Janeiro: Renovar, 2002.

CARREAU, Dominique; TREUHOLD, Robert. Le nouvelle loi de privatisation ou l'annonce prématurée de la mort de Colbert. Recueil Dalloz - chroniques, Paris, n. 32, p. 231-235, 1993.

. Privatisations, droit boursier et pratiques des marchés. Revue des Sociétés, Paris, n. 112, p. $1-23,1994$.

CARVAlHOSA, Modesto Souza Barros; EIZIRIK, Nelson. A nova lei das S.A. São Paulo: Saraiva, 2002.

CHEFFINS, Brian. Company law: theory, structure and operation. New York: Oxford University Press, 2000.

CIRENEI, Maria Teresa. Le società di diritto 'speciale' tra diritto comunitario delle società e diritto comunitario della concorrenza: società a partecipazione pubblica, privatizzazioni e 'poteri speciali' Diritto del Commercio Internazionale, Milano, n. XI, p. 771-829, 1996.

COSTI, Renzo. Privatizzazione e diritto delle società per azioni. Giurisprudenza commerciale, Milano, n. XXII, parte I, fasc. 1, p. 77-100, 1995.

DEL CASALE, Enrica. Uno strumento diretto di controllo governativo sulle privatizzazioni: le "golden shares". Politica del Diritto, Bologna, n. 1, p. 149-157, mar. 1988.

DEVROE, Wouter. Privatizations and community law: neutrality versus policy. Common Market Law Review, Leiden, n. 34, p. 267-306, 1997.

DI PORTO, Fabiana. Note sul regime giuridico delle privatizzazioni in Italia. In particolare nei servizi pubblici essenziali. Giurisprudenza Commerciale, Milano, n. XXVII, parte I, fasc. 6, p. 738$767,1999$.

DONAHUE, John D. The privatization decision - public ends, private means. New York: Basic Books, 1989.

DUMEZ, Hervé; Jeunemaitre, Alain. Les privatisations en France, 1986-1992. In: Wright, Vincent (Org.). Les privatisations en Europe - programmmes et problèmes. [s.1.]: Actes Sud, 1993. p. 105132.

DURUPTY, Michel. Le privatizzazioni in Francia. Rivista Trimestrale di Diritto Pubblico, Milano, n. 1, p. 44-85, 1988.

EUROPEAN COMMISSION. Special rights in privatised companies in the enlarged union: a decade full of developments. Commission Staff working document. 22 July 2005. Disponível em: <http:// ec.europa.eu/internal_market/capital/docs/privcompanies_en.pdf>. Acesso em: 17 abr. 2006. 
GRAHAM, Cosmo. Privatization - the United Kingdom experience. Brooklyn Journal of International Law, n. 21, p. 185-211, 1995.

. Regulating public utilities: a constitutional approach. Portland: Hart Publishing, 2000.

GRAHAM, Cosmo; PROSSER, Tony. Privatising nationalised industries: constitutional issues and new legal techniques. Modern law review, Oxford, n. 50, p. 16-51, 1987.

. Golden shares: industrial policy by stealth? Public law, Oxford, [s.n.], p. 413-431, 1988.

. Privatizing public enterprises: constitutions, the State and regulation in comparative perspective. New York: Oxford University Press, 1991.

GROUT, Paul. Popular capitalism. In: BISHOP, Matthew; KAY, John; MAYER, Colin (Org.). Privatization and economic performance. London: Oxford University Press, [s.d.]. p. 299-312

GRUNDMANN, Stefan; MÖSLEIN, Florian. Die GoldeneAktie-Staatskontrollrechte in Europarecht und wirtschaftspolitischer Bewertung. Zeitschrift für Unternehmens-und Gesellschaftsrecht, n. 32, p. 317-366, 2003.

. Golden shares - state control in privatised companies: comparative law, European law and policy aspects. Apr. 2003. Disponível em: $<$ http://ssrn.com/abstract=410580>. Acesso em: 16 jul. 2003.

GUERREIRO, José Alexandre Tavares. Regime jurídico do capital autorizado. São Paulo, 1983. Dissertação (Mestrado) -Faculdade de Direito, Universidade de São Paulo.

GUILLIEN, Raymond; MONTAGNIER, Gabriel. Lexique des termes juridiques. 13. ed. Paris: Dalloz, 2001.

IRTI, Natalino. L'ordine giuridico del mercato. 4. ed. Bari: Editori Laterza, 2001.

JAEGER, Pier Giusto. Privatizzazioni; "public companies"; problemi societari. Giurisprudenza Commerciale, Milano, n. XXII, parte I, fasc. 1, p. 5-19, 1995.

KRONENBERGER, Vincent. The rise of the "golden" age of free movement of capital: a comment on the golden shares judgments of the Court of Justice of the European Communities. European Business Organization Law Review, Hague, n. 4, p. 115-136, 2003.

LEÃES, Luis Gastão Paes de Barros. A sociedade anônima de capital autorizado não é novo tipo social. In: Direito comercial: textos e pretextos. São Paulo: José Bushatsky Editor, 1976. p. 267-281.

LIBONATI, Berardino. La faticosa "accelerazione" delle privatizzazioni. Giurisprudenza Commerciale, Milano, n. XXII, parte I, fasc. 1, p. 20-76, 1995.

LLOYD, Tracey; ROBERT, Gavin. Golden shares and European law. European Counsel, London, n. 2 , fasc. 10 , p. $37-40,1998$.

MARCHETTI, Piergaetano. Le privatizzazioni in Francia, Rivista delle Società, Milano, n. 39, fasc. 1-2, p. 264-268, genn./apr. 1994. 
. Le privatizzazioni in Italia: la legge 474/1994 e ulteriori documenti. Rivista delle Società, Milano, n. 39, fasc. 4, p. 748-764, luglio/ag. 1994.

. Nuovi sviluppi delle privatizzazioni. Rivista delle Società, Milano, n. 40, fasc. 5-6, p. 12741285, sett./dic. 1995 .

MARCHETTI, Piergaetano (Org.). Le privatizzazioni in Italia - saggi, leggi e documenti. Milano: Dott. A. Giuffrè Editore, 1995.

MEGGINSON, William L.; Netter, Jeffry M.. From State to market: a survey of empirical studies on privatisation. Journal of economic literature, Stanford, v. 39, n. 2, June 2001. Disponível em: $<$ http://ssrn.com/abstract=262311 $>$. Acesso em: 17 abr. 2006.

MINERVINI, Gustavo. Contro il diritto speciale delle imprese pubbliche "privatizzate". Rivista delle Società, Milano, n. 39, fasc. 4, p. 740-747, luglio/agosto 1994.

MORAES, Luiza Rangel de. Ação de classe especial - legalidade. Revista de Direito Bancário, do Mercado deCcapitais e da Arbitragem, São Paulo, n. 22, p. 129-155, out./dez. 2003.

MORENILLA, José María Souvirón. La privatización del sector publico empresarial del Estado en España (1996-2002). Aspectos jurídicos. In: ORTIZ, Gaspar Ariño (Org.). Privatizaciones y liberalizaciones en España: balance y resultados (1996-2003). Granada: Comares Editorial, 2004. t. I. p. $1-59$.

OPPO, Giorgio. Privatizzazioni: aspetti privatistici. MARASÀ, Giorgio (Org.). Profili giuridici delle privatizzazioni. Torino: G. Giappichelli Editore, 1997. p. 14-25.

OXERA CONSULTING LTD. Special rights of public authorities in privatised EU companies: the microeconomic impact. 2005. Disponível em: < http://www.europa.eu.int/comm/internal market/capital/docs/2005_10_special_rights_full_report_en.pdf > $>$. Acesso em: 20 abr. 2006. PÉZARD, Alice. L' action spécifique des sociétés privatisées. Droit et Pratique du Commerce International, Paris, t. 19, n. 3, p. 523-534, 1993.

. The golden share of privatized companies. Brooklyn Journal oflinternational Law, New York, n. 21, p. 85-95, 1995.

PIRIE, Madsen. Blueprint for a revolution. 2. ed. London: Adam Smith Institute (Research) Limited, 1993.

. et al. Privatização, mercado de capitais e democracia: a recente experiência internacional. Sem referência ao tradutor. Rio de Janeiro: Correio da Serra, 1988.

PUTEK, Christine O'Grady. Limited but not lost: a comment on the ECJ's golden share decisions. Fordham Law Review, New York, n. 72, p. 2.219-2.285, 2004.

REINHARD, Yves. Privatisation des enterprises. Revue Trimestrielle de Droit Commercial et de Droit Économique, Paris, n. 4, p. 670-673, oct./déc. 1993. 
RIPERT, Georges; ROBLOT, René. Traité de droit commercial. 17. ed. Paris: L.G.D.J., 1998. t. I. RODRIGUES, Nuno Cunha. Golden shares - as empresas participadas e os privilégios do Estado enquanto acionista minoritário. Coimbra: Coimbra Editora, 2004.

RUTABANZIBWA, Audax Peter. What is golden in the golden share? Company law implications of privatisation. Company Lawyer, London, n. 17, fasc. 2, p. 40-45, 1996.

SALERNO, Luigi. Golden shares. Interessi publici e modelli societari tra diritto interno e disciplina comunitaria. Diritto del Commercio Internazionale, Milano, n. XVII, p. 671-704, 2002.

SALOMÃO FILHO, Calixto. O novo direito societário. 2. ed. São Paulo: Malheiros, 2002.

SANTONASTASO, Felice. Le società di interesse nazionale. Milano: Dott. A. Giuffrè Editore, 2002.

SAUNDERS, Peter; HARRIS, Colin. Privatisation and popular capitalism. Buckingham: Open University Press, 1994.

SILVA, Luiz Alberto da. Transferência de ações ordinárias da Empresa Brasileira de Aeronáutica S.A. - Embraer - dos acionistas controladores da companhia a empresas francesas. Revista de Direito Bancário, do Mercado de Capitais e da Arbitragem, São Paulo, n. 8, p. 197-217, abr./jun. 2000.

SODI, Jacopo. Poteri speciali, golden share e false privatizzazioni. Rivista delle Società, Milano, n. 41, fasc. 2-3, p. 368-404, mar./giugno 1996.

SPADA, Paolo. Autorità e libertà nel diritto della società per azioni. Rivista di Diritto Civile, Padova, n. XLII, fasc. 6, p. 703-719, 1996.

VERHOEVEN, Amaryllis. Privatisation and the EC law: is the European commission "neutral" with respect to public versus private ownership of companies? International and Comparative Law Quarterly, Oxford, n. 4, p. 861-887, 1996.

VICKERS, John; YARROW, George. Privatization: an economic analysis. Cambridge: MIT Press, 1989. 